Portland State University

PDXScholar

\title{
Existing Ecological Conditions and Management Recommendations for a Portion of the Chehalem Ridge Nature Park, Oregon
}

Amanda Pole

Portland State University

Follow this and additional works at: https://pdxscholar.library.pdx.edu/mem_gradprojects

Part of the Environmental Health and Protection Commons, and the Natural Resources and Conservation Commons

Let us know how access to this document benefits you.

\section{Recommended Citation}

Pole, Amanda, "Existing Ecological Conditions and Management Recommendations for a Portion of the Chehalem Ridge Nature Park, Oregon" (2018). Master of Environmental Management Project Reports. 38. https://pdxscholar.library.pdx.edu/mem_gradprojects/38 https://doi.org/10.15760/mem.41

This Project is brought to you for free and open access. It has been accepted for inclusion in Master of Environmental Management Project Reports by an authorized administrator of PDXScholar. Please contact us if we can make this document more accessible: pdxscholar@pdx.edu. 


\title{
Existing Ecological Conditions and Management Recommendations
}

for a Portion of the Chehalem Ridge Nature Park, Oregon

\author{
by \\ Amanda Pole
}

\begin{abstract}
A project report submitted in partial fulfillment of the requirements for the degree of

Professional Science Master

in

Environmental Science and Management
\end{abstract}

Committee:

Advisor: Dr. Jeff Gerwing, Portland State University

Dr. Amy Larson, Portland State University

Project Partner: Kate Holleran, Oregon Metro 


\section{Executive Summary}

Effective land management and habitat restoration work rely on the collection of baseline information regarding the existing conditions of the planning area. Existing conditions assessments can include such information as hydrologic conditions, botanical species assessment, land use issues, wildlife surveys, habitat distribution/quality assessments, etc. This project provides Oregon Metro's Parks and Nature department with updated information regarding the existing conditions of a portion of the Chehalem Ridge Nature Park (CRNP) as well as recommendations and supplemental maps to aid in future management planning.

Within the 61-acre project area exist several habitat types: a developing seasonal wetland, riparian forest, Douglas-fir forest, and Oregon white oak. Previous land use and proximity of residential/agricultural property has altered the area in a variety of ways; most notable impacts include changes to the hydrologic conditions through the installation of roads and culverts that restrict natural water movement through the system and altered community structure due to the suppression of fire combined with introduction of non-native species. Because the Douglas-fir forest is the result of previous agro-forestry, the stands are even aged stands with high stem density and very little understory perpetuated by dense shade after herbicides previously applied by the timber industry. In contrast, the oak woodlands have abundant understory vegetation and conifer encroachment challenges, likely due to the suppression of fire in the region. The seasonal wetland area appears to be developing as a result of restricted hydrologic activity from the installation of SW Poppy Drive, a private asphalt road with culvert that restrict the surface water flow south of the wetland area of the park. Additionally, flooding in the area is influenced by seasonal variations in precipitation with saturated soils and several pools resulting from wet winter months, but only small areas of saturated soils and little to no pooling for most of the drier summer months. The seasonal nature of the wetland is congruent with the seasonal nature of the streams 
and spring. As a result, the majority of plants found in these areas tolerate a range of soil conditions from well-drained to saturated. During the dry season, both the wetland and riparian forest areas are incorporated into the oak woodland and Douglas-fir forest habitats that surround them.

Detailed management recommendations include suggestions for maintaining and enhancing the patchwork of habitats as well as other considerations such as erosion control and public access. In summary: resource limitations, the abundance/persistence of non-native plant species, and the ecosystem changes due to previous and current land use activities makes diverging from strict historical conditions and applying the novel ecosystem approach the most reasonable management plan for this area at this time. By focusing on community structure and ecosystem resilience, non-native species may be allowed to persist in a dynamically balanced system as long as they are not inhibiting plant diversity to such an extent that the system's resilience is threatened.

Because Oregon white oaks (Quercus garryana) are a valuable and threatened species in the PNW, they should be prioritized in this system by applying thinning treatments to mimic historical fire disturbance in order to maintain the desired conditions for oak longevity and fecundity. Wetland enhancement may be achieved through the suppression of reed canary grass populations that inhibit plant diversity. Mimicking beaver activity through the installation of small wood dams can restrict water flow and prolong the flooded/saturated periods, thus increasing the amount of wetland habitat. Metro's current plans and thinning treatments for the Douglas-fir forest within CRNP are intended to accelerate the development of old-growth forest structure. The additional recommendation for this area is to periodically push back the Douglas-fir boundary to maintain/increase the oak habitat by removing all encroaching conifers.

Finally, this area also has strong potential for increased public access. The area could be an excellent social, educational, and cultural resource. With the installation of trails, regular maintenance in the area would be easier and reduction of erosion and habitat 
damage from off-trail recreation activities in the area may be mitigated. Trails would also enable events such as acorn harvesting in partnership with local tribes which could enhance cultural awareness and social value for oak habitat. Trails could also facilitate partnership projects with educational institutions to take advantage of abundant research and monitoring opportunities. 


\section{Dedication}

This project is dedicated to my father, Edwin James Pole II, who has been my pillar of support and confidence. Your pride in me is my greatest treasure. 


\section{Acknowledgements}

I would like to thank Dr. Jeff Gerwing and Dr. Amy Larson for their guidance and support bringing this project to fruition. I would also like to thank Kate Holleran and Oregon Metro Parks and Nature for the opportunity to work on such a complex and exciting project with meaningful real-world implications. A special thanks to my co-workers at Metro Central Hazardous Waste Facility for their support and flexibility accommodating my educational pursuits, and to my cohort at PSU for their comradery on this journey. And lastly, to my soul-family, Cori Escalante-Zerega, Andrew Gosnell, Danielle Cintron, Mary MacNicol, and Adam Mayfield, for continuously plying me with your confidence, pride, and encouragement. 


\section{$\underline{\text { Table of Contents }}$}

\section{Page}

Executive Summary

i

Dedication $\quad$ iv

Acknowledgements $\quad \mathrm{v}$

List of Tables and Figures $\quad$ ix

Introduction 1

Project Description and Purpose 3

Background Information 4

Chehalem Ridge Nature Park $\quad 4$

Habitat Significance $\quad 5$

Wetland Habitat Value and Characteristics 6

$\begin{array}{lc}\text { Riparian Forest Value and Characteristics } & 8\end{array}$

Oak Woodland Habitat Value and Characteristics 9

$\begin{array}{ll}\text { Douglas-fir Forest Value and Characteristics } & 10\end{array}$

$\begin{array}{ll}\text { Methods } & 16\end{array}$

$\begin{array}{ll}\text { Field Observations and Data Collection } & 16\end{array}$

$\begin{array}{ll}\text { Overview } & 16\end{array}$

$\begin{array}{ll}\text { Hydrologic Features } & 16\end{array}$

$\begin{array}{ll}\text { Botanical Surveys } & 17\end{array}$

$\begin{array}{ll}\text { Data Processing and Analysis } & 18\end{array}$

$\begin{array}{ll}\text { Precipitation Analysis } & 18\end{array}$

$\begin{array}{ll}\text { Photo Identification } & 20\end{array}$

$\begin{array}{ll}\text { Map Creation } & 20\end{array}$

$\begin{array}{ll}\text { Existing Conditions } & 21\end{array}$

$\begin{array}{ll}\text { Soils } & 21\end{array}$

$\begin{array}{ll}\text { Riparian Forest } & 22\end{array}$

$\begin{array}{ll}\text { Streams Outside Project Area } & 22\end{array}$ 


\section{Table of Contents}

Page

Streams Inside Project Area $\quad 23$

Developing Seasonal Wetland 25

$\begin{array}{ll}\text { Oak Woodland Forest } & 28\end{array}$

Douglas-fir Forest $\quad 31$

$\begin{array}{ll}\text { Botanical Summary } & 31\end{array}$

$\begin{array}{ll}\text { Invasive Species } & 32\end{array}$

$\begin{array}{ll}\text { Wildlife } & 34\end{array}$

$\begin{array}{ll}\text { Human Use } & 35\end{array}$

Management Recommendations 36

Assumptions 36

$\begin{array}{ll}\text { Setting Priorities } & 36\end{array}$

Increasing Oak Woodland Habitat and Enhancing Oak Viability 38

Enhancing Quality and Quantity of Wetland Habitat 40

Douglas-fir Forest $\quad 43$

Invasive Species Management $\quad 44$

Erosion Control 45

Fire Roads $\quad 45$

$\begin{array}{ll}\text { Culverts } & 46\end{array}$

$\begin{array}{ll}\text { Accessibility } & 47\end{array}$

$\begin{array}{ll}\text { Trails } & 47\end{array}$

Community Outreach $\quad 49$

$\begin{array}{ll}\text { Education } & 49\end{array}$

$\begin{array}{lr}\text { Summary Statement } & 50\end{array}$

$\begin{array}{ll}\text { References } & 51\end{array}$ 


\section{Table of Contents}

$\begin{array}{ll}\text { Appendix A - Botanical Species Information } & 57 \\ \text { Botanical Summary Table } & 57 \\ \text { Botanical Species List } & 57 \\ \text { Wetlands Status Abbreviations Key } & 62 \\ \text { Authority Abbreviations Key } & 63 \\ \text { Appendix B-Maps } & 64 \\ \text { Project Area } & 64 \\ \text { Plant Surveys } & 65 \\ \text { Rain Gauge Locations } & 66 \\ \text { Current Habitat Distribution } & 67 \\ \text { Recommended Habitat Distribution } & 68 \\ \text { Invasive Species Distribution } & 69\end{array}$




\section{List of Tables and Figures}

Label

Description

Page

Table 1 Cross-referenced list of wildlife species known to be present in CRNP from previous wildlife survey and the habitats in the project area they may utilize.

Figure 1 Chehalem Ridge Area Map (created by Metro 2016).

Figure 2 Hydrograph of average monthly precipitation.

Figure 3 Bar graph of average rainy season precipitation

Figure $4 \quad$ Photo: Condition of stream on eastern end of fire road. 22

Figure 5 Photo: Condition of western-most stream head at Dixon Mill culvert. 23

Figure 6 Photo: Condition of western-most stream at base of the slope. 23

Figure $7 \quad$ Photo: One of several rivulets that disperse water into wetland area. 24

Figure 8 Photo: Once of several shallow pools in the wetland area illustrating 24 wetland conditions early in the season.

Figure 9 Photo: Horsetail bus in rivulets and saturated soil at base of slope. 26

Figure 10 Photo: Example of patchwork habitat with shifting dominant 26 vegetation.

Figure 11 Photos: Comparison of water level of highest elevation wetland pool. 27

Figure 12 Photo: Downed tree with root ball in saturated wetland area. 28

Figure 13 Photos: Examples of oak crown shapes and associated competition 29 found in the area.

Figure 14 Photo: Example of species groups competing for resources in a small 30 area.

Figure 15 Photo: Large clump of Himalayan blackberry along the western park boundary fence.

Figure 16 Photo: Apple galls found on OWO leaf. 


\section{List of Tables and Figures}

Label Description

Page

Figure 17 Photos: Examples of insects observed in the project area.

Figure 18 Photos: Examples of animal remains found in various areas of the 35 project area.

Figure 19 Diagram: Example of trail grading model to reduce erosion impacts from precipitation and surface flow. 


\section{Introduction}

Effective ecological restoration projects benefit from a multiphase planning process that culminates in a comprehensive project plan with clearly defined restoration/management goals; evaluation of a site's existing conditions provides the foundation for both developing the plan as well as evaluating project outcomes (Rieger et al., 2014). Understanding the existing conditions of a site help land managers determine project priorities and establish attainable management/restoration plans. These plans can be influenced by a variety of considerations such as historical reference sites, habitat loss/value, public interests/cultural value, and climate change (White \& Walker, 1997, Landres et al., 1999; SER, 2004; Laughlin et al., 2017; Johnson et al., 2017; Butterfield et al., 2017; Suding et al., 2004; Garibaldi \& Turner, 2004; Vesely \& Tucker, 2004; Anderson, 2007). Having clear goals with accurate information on the existing conditions is crucial for both planning and evaluating any project (Rieger et al., 2014). Adaptive management practices have become a prominent focus for addressing the inherent complexities and unpredictable nature of restoration projects (Rieger et al., 2014; Bormann et al., 2007). For this reason, the planning process should be adaptive and iterative as new information is discovered (Rieger et al., 2014). This can require updated existing conditions assessments for project areas within an existing plan.

Oregon Metro Parks and Nature (Metro), a department of the regional government agency serving the greater Portland metro area, completed the planning process for the Chehalem Ridge Nature Park (CRNP) in 2013, culminating in their 2014 conservation plan based on existing and historic conditions, Metro's overarching natural resource conservation goals, and public access/interests (Metro, 2014). When initial evaluations were performed, the area south of SW Dixon Mill Rd. (the only road that cuts across the park, outlined in red in Figure 1) had largely been deemed too steep and sensitive to landslides for restoration work to be performed safely, with only a few select activities allowed within this section. 


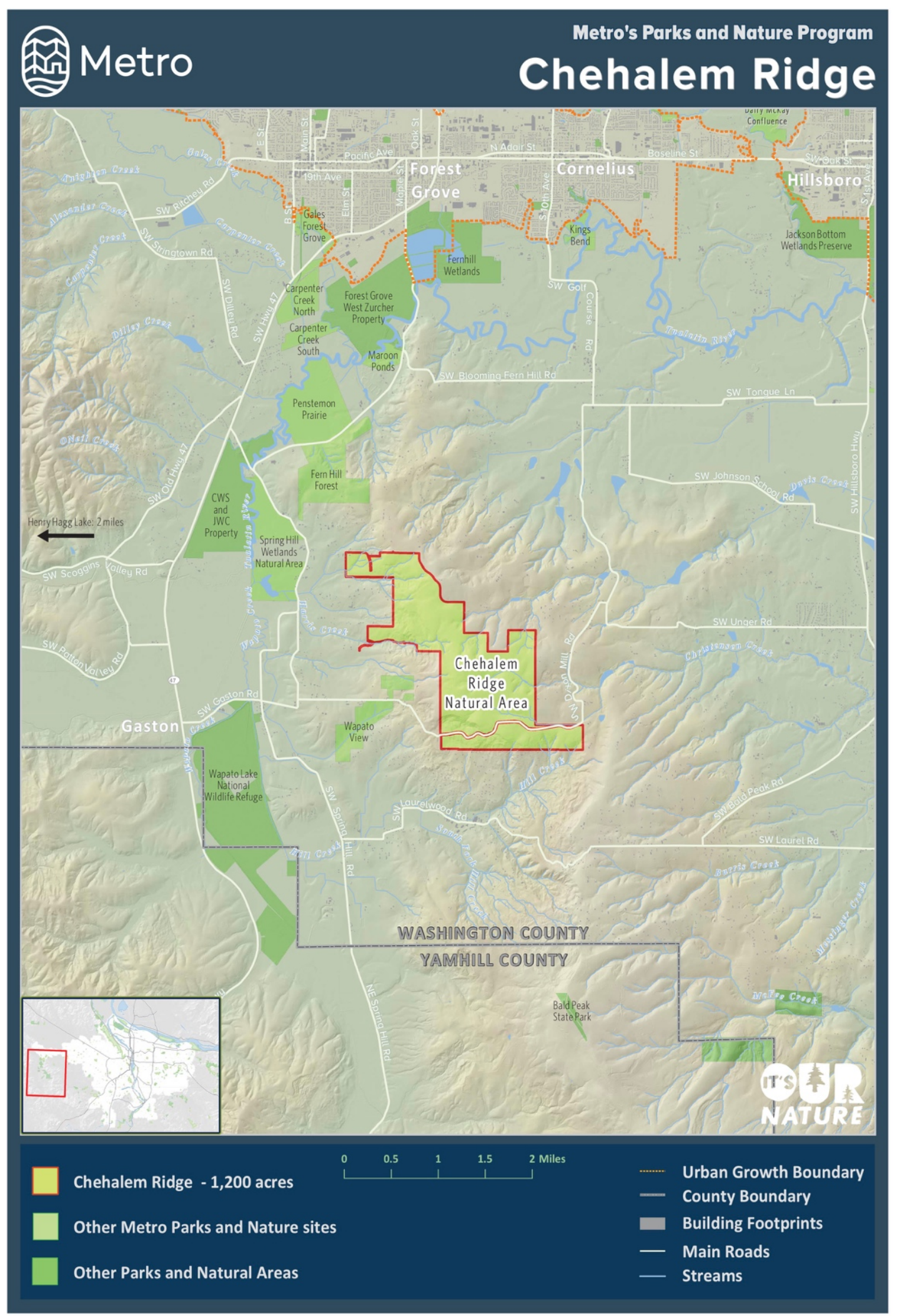

Figure 1: Chehalem Ridge area map (created by Metro, February 2016, available at: https://www.oregonmetro.gov/chehalem-ridge-nature-park-access-master-plan). 
The ridge-top portions of this area, which were previously used for a Douglas-fir tree farm, were included in the thinning plans applied to the rest of the park. Some invasive species removal, native species plantings, and limited oak-release (removal of competing vegetation to increase light availability for the oaks) were done in the western end of this section. While the steep slope and landslide issues are present in the eastern end of this section, it became apparent that some portion of the western end could be suitable for management activities because the slopes are not as steep and moderate soil disturbances are unlikely to cause landslides like those that previously occurred in the eastern end of this section. The previously unidentified, developing wetland area was also recognized at this time. This potential wetland habitat and presence of valuable Oregon white oaks spurred Metro's interest in collecting updated information about the conditions of the area to aid in future management planning.

\section{Project Description and Purpose}

The purpose of this project is to aid Metro's future land management and restoration planning for the manageable portion (outside the potential landslide zone) of the Chehalem Ridge Nature Park south of Dixon Mill Rd. To that end, this project includes the following elements specifically related to 61 acres at the western end where management activities are unlikely to cause landslides:

1) Existing Conditions - a report of ecological observations and data collected during field visits to the areas outside the previously identified landslide area.

2) Botanical Species List (Appendix A) - Metro requires a list of plant species found in the area to provide a "baseline for the presence of native and non-native species at a point in time" (Kate Holleran, personal communication).

3) Management Recommendations - suggested restoration and land management goals and activities based on the existing conditions and supplemental research.

4) Supplemental Maps (Appendix B) - a collection of maps illustrating various aspects of the preceding elements. 


\section{Background Information}

\section{Chehalem Ridge Nature Park}

Metro acquired 1,196 acres for the Chehalem Ridge Nature Park (CRNP) between 2006 and 2011 through a 2006 natural areas bond measure (Metro, 2014). CRNP is now the largest natural area in Washington County (Figure 1), with five perennial streams within the Tualatin watershed (Metro, 2014). The recent (post colonization) land use history for the property is primarily agricultural, including time periods used as farmland, orchards, and, most recently, a Douglas fir tree farm (Metro, 2014). Metro's restoration and management plan aims to improve watershed conditions and enhance wildlife habitat through strategic silvicultural prescriptions and conservation of highly valued habitats (Metro, 2014). These plans also include enhancing recreation and education opportunities for the community (Metro, 2014). Current restoration activities throughout CRNP include tree thinning, oak-release, invasive species removal, native plantings, and stream restoration (Kate Holleran, personal communication, 2016 2018).

The section of CRNP evaluated in this report contains several habitat types including riparian forest, Douglas-fir forest, Oregon white oak (OWO) woodlands, and a developing seasonal wetland. Although the project area is only 61 acres, this patchwork of habitat is a miniature representation of the patchy habitat mosaic observed by early settlers across the Pacific Northwest (PNW) landscape (Thilenius, 1968; Thompson, 2007). It is now generally understood that this patchwork of habitat types in the Pacific Northwest was greatly influenced by indigenous cultural and land management practices by tribes such as the Kalapuya and Chehalis of the PNW (Anderson, 2007; Thilenius, 1968; Vesely \& Tucker, 2004; Thompson, 2007; Pellatt et al., 2015). These indigenous peoples practiced seasonal burning which created habitat edges beneficial for hunting (Thilenius, 1968) as well as improving acorn abundance and general oak health (Anderson, 2007); they also used plant management techniques which enhanced valuable food sources, such as camas and tarweed within these 
systems (Vesely \& Tucker, 2004). While this patchwork habitat structure is culturally significant, it also has ecological value.

Let us consider the idea that biological diversity supports ecosystem resilience and habitat diversity is necessary for higher levels of biological diversity (USDA Forest Service, 2016; Downing et al., 2012; Spasojevic et al., 2016). Huston's (1979) “dynamic equilibrium model" supports the idea that periodic disturbances, like the ones employed by the Kalapuya to manage oak habitat, help to maintain diversity by reducing population sizes and preventing "competitive exclusions" as long as they are not so frequent that competing species cannot recover between disturbances. The frequency of disturbance creates a dynamic balance that defines the systems level of diversity (Huston, 1979). Downing et al. (2012) shows that there is a level of diversity of native species necessary to maintain a system's resilience to invasion, while Laughlin et al. (2017) suggest that trait-based plant selection may provide greater resilience in a changing climate. Therefore, a dynamic balance between native and non-native species may be ideal for long-term ecosystem resilience. The level of disturbance necessary to maintain the kind of patchwork habitat structure found in this section of CRNP can create/maintain the biological diversity necessary for such resilience. By evaluating the existing conditions of the site, land managers can strategically mimic historical disturbance regimes, control select populations of dominating/invasive species, and increase competition by introducing extant species or species with desired traits in order to improve diversity and resilience of the overall system.

\section{Habitat Significance}

While this patchwork habitat and its associated diversity and resilience are ecologically and culturally valuable as a whole, each habitat type within the patchwork has unique characteristics and values that should be evaluated independently. It is important to clarify why each habitat type is important to conserve and/or enhance within the 
patchwork as well as the various habitat characteristics to consider in the context of this report.

\section{Wetland Habitat Value and Characteristics}

Wetlands provide important ecosystem services with local and regional impacts. For example, wetlands provide crucial habitat to a variety of species including amphibians, reptiles, mammals, and resident and neotropical migratory birds, many of which are already known to be present in CRNP (The Intertwine Alliance, 2012; Metro, 2014). There are 76 animals known to exist in CRNP that may utilize the wetland area, 3 of which (cackling goose (Banta Canadensis), Canada goose (Branta hunchinsii minima), and mallard duck (Anas platyrhynchose)) are solely dependent on wetland habitat (Table 1). The animals supported by this habitat have ecological value as they span the food web and, in some cases, act as ecosystem engineers, such as the American beaver (Castor canadensis); they also have economic value (e.g. hunting and bird watching can be valuable recreation activities within a community).

In addition to habitat value, another important ecosystem service of wetlands is improved water quality. Wetlands affect water quality in a dynamic way depending on a variety of factors such as the hydrologic signature, soil texture, erosion control, and plant composition (Moreno-Mateos et al., 2012; Mitsch \& Gosselink, 2015). The retention of water in pools and soil increases residence times, providing opportunities for microbes and plants to breakdown and/or consume contaminants (Verhoeven et al., 2006; Lautz \& Fanelli, 2008; Mitsch \& Gosselink, 2015). Because the area has historically been used for agricultural purposes where various pesticides may have been applied, it is possible for residual legacy pesticides and heavy metals that persist in the soil matrix to be hydrologically transported. Increased residence times in redox conditions may provide a valuable mechanism for improving local water quality, which can affect habitat quality as well as human use. 
Wetland delineation is a complex issue because there is great variability in wetland types. Furthermore, there are a variety of methods used to delineate wetlands that serve different goals, such as for legal protection, land management planning, and/or scientific research (Mitsch \& Gosselink, 2015). The soils, species composition, locations, and water retention of PNW wetlands differ from other wetland areas of the US to such extent that the US Army Corps of Engineers created a regionally specific wetland delineation guide (Environmental Laboratory, 2010). Because the US Army Corps definition of wetlands is an accepted definition for legal purposes, land management, and ecological studies in the US, I rely on their wetland definition: "Those areas that are inundated or saturated by surface or ground water at a frequency and duration sufficient to support, and that under normal circumstances do support, a prevalence of vegetation typically adapted for life in saturated soil conditions." (Environmental Laboratory, 1987; Mitsch \& Gosselink, 2015).

While legal delineation uses the US Army Corps' technical guidelines which require the presence of three positive indicators (vegetation, soil, and hydrology) the US Fish and Wildlife Service's system requires just one of the three indicators be present (Environmental Laboratory, 1987). Therefore, for Metro's land management purposes, the wetland boundary shall be primarily characterized by hydrology, using saturated soils during a "significant portion of the growing season" (Environmental Laboratory, 1987) for defining the habitat boundary. While there is no specific length of time defined by the Army Corps of Engineers, a common practice in PNW wetland delineation is to assess saturation zones at least 21 days after the growing season begins (Peggy O’Neil, Portland State University Instructor, personal communication).

Although the soil conditions may need to be evaluated at a later time for establishing legal wetland delineation protections, incorporation into a wetland banking system, or permitting restoration activities designed to increase the wetland area, that is not required for the function of this report or Metro's land management planning at this 
time. Furthermore, it is likely that the interactions of hydrology and hydrophilic vegetation will eventually guarantee that all three wetland characteristics necessary for official legal delineation will be present over time (Mitsch \& Gosselink, 2015). Therefore, because legal delineation is not my purpose, but rather land management for maintaining quality habitat, evaluation of the soil chemistry or physical characteristics beyond saturation was not necessary at this time.

\section{Riparian Forest Value and Characteristics}

The streams in this project area are seasonal, first-order streams that are dry most of the year. While they do not support fish, they can provide seasonal support for amphibians such as the red-legged frog and chorus frogs known to inhabit the park (The Intertwine Alliance, 2012; Metro, 2014), as well as provide important water resources for other animals. All of the following factors that define the qualities of riparian forests can affect water and habitat quality within these systems.

The riparian zone is typically considered the flood plain associated with a given river or stream, although this area may be extended along steep slopes (Kate Holleran, personal communication, 2018). Riparian forest conditions are highly variable depending on factors such as geology/soil, stream order/hydrology, natural disturbances, and previous land use. All three factors will influence the conditions of a riparian zone and associated management plans. The riparian vegetation can vary greatly depending on the habitat type(s) the stream cuts through. The vegetation affects factors such as stream temperature (via shading), organic debris load, erosion, and water infiltration/runoff rates while the hydrologic signature affects the vegetation by the reduced shear strength of (periodically) saturated soils resulting in greater windthrow potential (Edmonds et al., 2011). Land use patterns, such as urban development with impervious surfaces (e.g. roads) and clear-cut logging, can cause increases to flooding, sediment loads (erosion/incising), and temperatures (Barnes et al., 1998; Edmonds et al, 2011; Mohr et al., 2013). These interactions can also affect the hyporheic zone function as 
residence times and water chemistry are influenced by patterns of downwelling and upwelling resulting from soil texture and pooling patterns (Tonina \& Buffington, 2007).

\section{Oak Woodland Habitat Value and Characteristics}

Oregon white oaks (OWO) and their associated habitats have been greatly diminished due to discontinuing Native American seasonal burning traditions, increased conifer encroachment, invasive species, and changes in land use such as urbanization and agriculture (Vesely \& Tucker, 2004; Thompson, 2007; Dunwiddie \& Bakker, 2011; Pellatt \& Gedalof, 2014; Pellat et al., 2015). OWO habitat was once widespread from California, through Oregon and Washington and into British Columbia, with an historic estimate of more than 500,000 acres (Vesely \& Tucker, 2004). As of 2007, only about 10 percent remained and was of poor quality (Thompson, 2007), though numerous restoration projects throughout the PNW have focused on improving/increasing OWO habitat since Thompson's 2007 analysis. Many native plant and animal species co-evolved with Native American land management practices and are dependent on this habitat (Vesely \& Tucker, 2004). There are more than 200 wildlife species that utilize OWO habitat, 78 of which are known to exist in CRNP (Table 1); some are imperiled due to habitat loss (e.g. the Western Grey Squirrel (Sciurus griseus) and the Acorn Woodpecker (Melanerpes formicivorus)) (Vesely \& Tucker, 2004). Given their use as a cultural food source and crafting material for PNW tribes (Anderson, 2007), OWO are culturally significant and could be considered a "cultural keystone species" (Garibaldi and Tucker, 2004). Their removal from the landscape could negatively impact both the local ecology as well as the cultural heritage of local tribes. Therefore, preserving, protecting, and restoring OWO habitat has a variety of social and ecological values.

As a species, OWO may also be resilient to climate change. With projected temperature increases in Oregon of $1.2^{\circ} \mathrm{C}$ to $5.9^{\circ} \mathrm{C}$ by 2080 (depending on greenhouse gas emission rates) (Dalton et al., 2017), it is relevant to note that the fossil pollen record indicates that OWO had reached a "maximum extent in coastal British Columbia 7500 years 
[ago] when [the] climate was $2^{\circ} \mathrm{C}$ to $4 \stackrel{\circ}{ } \mathrm{C}$ warmer than present" (Pellatt \& Gedalof, 2014). Pellatt et al.'s (2012) climatic and precipitation modeling has also predicted increases to suitability for OWO habitat in areas that are geographically related to Chehalem Ridge Nature Park. Therefore, managing for this cultural keystone species and habitat has long term viability.

OWO habitat structure can range from open savannahs dominated by grasses to woodland forests with open canopies that incorporate mixed hardwood trees and an understory dominated by grasses, forbs and small shrubs (The Intertwine Alliance, 2012). In this project area the structure is primarily oak woodlands with areas of open canopy intermixed with patches dominated by small shrubs as well as some closed canopy portions of mixed hardwoods.

\section{Douglas-fir Forest Value and Characteristics}

Douglas-fir trees are a valuable forest commodity, often used in agricultural tree farms for producing lumber, as is the case on the land acquired for CRNP. However, Douglas-fir forests are also ecologically valuable. These forests can provide habitat to a wide range of animals, depending on the forest structure which changes over time in response to the disturbance regime (The Intertwine Alliance, 2012; Barnes et al, 1998). Although Metro's long-term trajectory is to create old-growth forest structure, in the immediate to near future, after thinning operations are completed, the Douglas-fir forests in this area will likely display early to middle seral stage structure for some time. This habitat structure will be immediately beneficial to 16 animals already known to exist in the CRNP as of 2012 and will increase to as many as 33 animals as mid to late seral stage structure develops (Metro, 2014; The Intertwine Alliance, 2012) (Table 1).

It is also worth noting that Douglas-firs dominated the conifer forests during the warmest and driest post glacial periods in the PNW (Barnes et al., 1998) and are therefore a potentially viable species for "trait-based selection" in regards to climate change (Laughlin et al, 2017), similarly to the oaks previously discussed. However, Ford 
et al. (2017) found that temperature, photoperiod, and geographic seed source affect the timing of growth cessation and that summer heat waves can induce early cessation in Douglas-fir. Therefore, while the species is generally well adapted to hot, dry conditions, there may be some variability in their growth rates depending on the tree farm seed source. This may also impact the amount of time necessary to achieve oldgrowth structure in these forests.

Douglas-fir is a major component of PNW conifer forests (along with spruce, western hemlock, true firs, and western red cedars), often the dominant tree in old growth habitat characterized by a heterogeneous canopy structure and multi-layered understory where shade tolerant species wait to move into the upper canopy when gaps are created from periodic disturbances (Barnes et al., 1998). Monocultures of Douglas-fir have also become prevalent in the region due to agroforestry, as is the case at CRNP. Douglas-fir forests can have a variety of forest structures depending on the disturbances that influence its development (Van Pelt, 2007). In natural disturbance regimes, biological legacies (snags and logs on the forest floor) are created that contribute to the creation of various habitats for cavity nesting birds and small mammals (Van Pelt, 2007, USDA Forest Service, 2016). Therefore, it is important for silviculture treatments to mimic the creation of such legacy features when attempting to create old-growth structure in areas like CRNP. 
Table 1: Cross-referenced list of wildlife species known to be present in CRNP from Metro's previous wildlife survey (Metro, 2014) and the habitats in the project area they may utilize (The Intertwine Alliance, 2012).

\begin{tabular}{|c|c|c|c|c|c|c|c|}
\hline & \multirow{2}{*}{\multicolumn{2}{|c|}{ Species }} & \multicolumn{5}{|c|}{ Habitat Type } \\
\hline & & & \multirow[b]{2}{*}{ Wetland } & \multirow{2}{*}{$\begin{array}{c}\text { Oak } \\
\text { Woodland }\end{array}$} & \multicolumn{3}{|c|}{ Douglas-fir Forest Seral Stage } \\
\hline & Common Name & Scientific Name & & & Early & Middle & Late \\
\hline \multirow{6}{*}{ 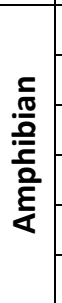 } & Dunn's Salamander & Plethodon dunni & & & & $x$ & $\mathrm{x}$ \\
\hline & Ensatina & Ensatina eschscholtzii & & $x$ & $x$ & $x$ & $x$ \\
\hline & Northwestern Salamander & Ambystoma gracile & $x$ & & & $x$ & \\
\hline & Northern Red-legged Frog & Rana aurora aurora & $x$ & $\mathrm{x}$ & & $x$ & $x$ \\
\hline & Pacific (chorus) Treefrog & Psuedacris regilla & $x$ & $x$ & & $\mathrm{x}$ & $x$ \\
\hline & Rough-skinned Newt & Taricha granulosa & $x$ & $x$ & & & \\
\hline \multirow{3}{*}{ 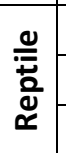 } & Common Garter Snake & Thamnophis sirtalis & $\mathrm{x}$ & $\mathrm{x}$ & & & \\
\hline & Southern Alligator Lizard & Sceloporus occidentalis & $x$ & $x$ & & & \\
\hline & Rubber Boa & Charina bottae & $x$ & $\mathrm{x}$ & & $\mathrm{x}$ & $x$ \\
\hline \multirow{15}{*}{ 흠 } & American Crow & Corvus branchyrhynchos & $x$ & $x$ & & & \\
\hline & American Goldfinch & Spinus psaltria & $x$ & $x$ & & & \\
\hline & American Robin & Turdus migratorius & $x$ & $x$ & $x$ & $x$ & $x$ \\
\hline & Anna's Hummingbird & Calypte anna & $x$ & $x$ & & & \\
\hline & Band-Tailed Pigeon & Patagioenas fasciata & $x$ & $x$ & & & \\
\hline & Bewick's Wren & Thyomanes bewickii & $x$ & $x$ & & & \\
\hline & Black-capped Chickadee & Poecile atricapilla & $x$ & $x$ & $x$ & $x$ & \\
\hline & Black-headed Grosbeak & Pheucticus melanocephalus & $x$ & $x$ & & & \\
\hline & Black-throated Gray Warbler & Setophaga nigrescens & $x$ & $x$ & & & \\
\hline & Brown Creeper & Certhia americana & $x$ & $x$ & $x$ & $x$ & $x$ \\
\hline & Brown-headed Cowbird & Molothrus ater & $x$ & $x$ & & & \\
\hline & Cackling Goose & Branta hunchinsii minima & $x$ & & & & \\
\hline & Canada Goose & Banta Canadensis & $x$ & & & & \\
\hline & Cedar Waxwing & Bombycilla cedrorum & $x$ & $x$ & & & \\
\hline & Chestnut-Backed Chickadee & Poecile rufescens & $x$ & $\mathrm{x}$ & & $x$ & $\mathrm{x}$ \\
\hline
\end{tabular}




\begin{tabular}{|c|c|c|c|c|c|c|c|}
\hline & \multirow{2}{*}{\multicolumn{2}{|c|}{ Species }} & \multicolumn{5}{|c|}{ Habitat Type } \\
\hline & & & \multirow[b]{2}{*}{ Wetland } & \multirow{2}{*}{$\begin{array}{c}\text { Oak } \\
\text { Woodland }\end{array}$} & \multicolumn{3}{|c|}{ Douglas-fir Forest Seral Stage } \\
\hline & Common Name & Scientific Name & & & Early & Middle & Late \\
\hline \multirow{26}{*}{ 홍 } & Common Raven & Corus corax & $x$ & $x$ & & & \\
\hline & Common Yellowthroat & Geothlypis trichas & $x$ & $x$ & & & \\
\hline & Cooper's Hawk & Accipiter cooperii & $\mathrm{x}$ & $\mathrm{x}$ & & & \\
\hline & Dark-eyed Junco & Junco hyernalis & $\mathrm{x}$ & $\mathrm{x}$ & $\mathrm{x}$ & $\mathrm{x}$ & $\mathrm{x}$ \\
\hline & Downy Woodpecker & Picoides pubescens & $x$ & $x$ & & $x$ & $x$ \\
\hline & Evening Grosbeak & Coccothraustes vespertinus & $x$ & $x$ & & $x$ & $x$ \\
\hline & Fox Sparrow & Passerella iliaca & $\mathrm{x}$ & $\mathrm{x}$ & & & \\
\hline & Golden-crowned Kinglet & Regulus setrapa & $\mathrm{x}$ & $\mathrm{x}$ & $\mathrm{x}$ & $\mathrm{x}$ & $\mathrm{x}$ \\
\hline & Great Blue Heron & Ardea herodias & $x$ & $x$ & & & \\
\hline & Great Horned Owl & Bubo virginianus & $x$ & $x$ & & & \\
\hline & Hairy Woodpecker & Picoides villosus & $x$ & $x$ & & $x$ & $x$ \\
\hline & Hermit Thrush & Catharus guttatus & $x$ & $x$ & & & \\
\hline & Hermit Warbler & Setophaga occidentalis & $x$ & $\mathrm{x}$ & $x$ & $\mathrm{x}$ & $\mathrm{x}$ \\
\hline & House Finch & Carpodacus mexicanus & $x$ & $x$ & & & \\
\hline & House Wren & Troglodytes aedon & $x$ & $x$ & $x$ & $x$ & \\
\hline & Hutton's Vireo & Vireo huttoni & $x$ & $x$ & $x$ & $x$ & $x$ \\
\hline & Lazuli Bunting & Passerina amoena & $x$ & $x$ & & & \\
\hline & MacGillivray's Warbler & Geothlypis tolmie & $x$ & $x$ & & & \\
\hline & Mallard Duck & Anas Platyrhynchose & $x$ & & & & \\
\hline & Mourning Dove & Zenaida macroura & $x$ & $x$ & & & \\
\hline & Northern Flicker & Colaptes auratus & $x$ & $x$ & & & \\
\hline & Olive-sided Flycatcher & Contopus cooperi & $x$ & & & $\mathrm{x}$ & $x$ \\
\hline & Orange-crowned Warbler & Oreothlypis celata & $x$ & $x$ & $x$ & $\mathrm{x}$ & $x$ \\
\hline & Pacific Wren & Troglodytes pacificus & $x$ & $x$ & & $x$ & $x$ \\
\hline & Pacific-slope Flycatcher & Empidonax dificilus & $x$ & $\mathrm{x}$ & $\mathrm{x}$ & $\bar{x}$ & $\mathrm{X}$ \\
\hline & Pileated Woodpecker & Dryocopus pileatus & $x$ & $x$ & & $x$ & $x$ \\
\hline
\end{tabular}




\begin{tabular}{|c|c|c|c|c|c|c|c|}
\hline & \multirow{2}{*}{\multicolumn{2}{|c|}{ Species }} & \multicolumn{5}{|c|}{ Habitat Type } \\
\hline & & & \multirow[b]{2}{*}{ Wetland } & \multirow{2}{*}{$\begin{array}{c}\text { Oak } \\
\text { Woodland }\end{array}$} & \multicolumn{3}{|c|}{ Douglas-fir Forest Seral Stage } \\
\hline & Common Name & Scientific Name & & & Early & Middle & Late \\
\hline \multirow{26}{*}{ 몽 } & Pine Siskin & Carduelis pinus & $x$ & $x$ & & $\mathrm{x}$ & $\mathrm{x}$ \\
\hline & Purple Finch & Carpodacus purpureus & $x$ & $x$ & & & \\
\hline & Red Crossbill & Loxia curvirostra & $\mathrm{x}$ & $\mathrm{x}$ & & $\mathrm{x}$ & $\mathrm{x}$ \\
\hline & Red-breasted Nuthatch & Sitta canadensis & $\mathrm{x}$ & $\mathrm{x}$ & & $\mathrm{x}$ & $\mathrm{x}$ \\
\hline & Red-breasted Sapsucker & Sphyrapicus ruber & $x$ & $x$ & & & \\
\hline & Red-tailed Hawk & Buteo jamaicensis & $\mathrm{x}$ & $\mathrm{x}$ & & & \\
\hline & Ring-necked Pheasant & Phasianus colchicus & $\mathrm{x}$ & $\mathrm{x}$ & & & \\
\hline & Ruby-crowned Kinglet & Regulus calendula & $x$ & $\mathrm{X}$ & & & \\
\hline & Ruffed grouse & Bonasa umbellus & $x$ & $\mathrm{x}$ & & & \\
\hline & Rufous Hummingbird & Selasphorus rufus & $x$ & $x$ & & & \\
\hline & Sharp-shinned Hawk & Accipiter striatus & $x$ & $\mathrm{X}$ & & & \\
\hline & Song Sparrow & Melospiza melodia & $x$ & $x$ & $\mathrm{X}$ & $\mathrm{X}$ & $x$ \\
\hline & Spotted Towhee & Pipilo maculatus & $x$ & $\mathrm{x}$ & & & \\
\hline & Steller's Jay & Cyanocitta stelleri & $x$ & $x$ & & & \\
\hline & Swainson's Thrush & Catharus ustulatus & $x$ & $\mathrm{x}$ & & & \\
\hline & Townsend's Warbler & Dendroica townsendi & & $x$ & & $\mathrm{x}$ & $x$ \\
\hline & Turkey Vulture & Cathartes aura & $x$ & $x$ & & & \\
\hline & Varied Thrush & Ixoreus naevius & & $x$ & & $x$ & $\mathrm{x}$ \\
\hline & Warbling Vireo & Vireo gilvus & $x$ & $x$ & & & \\
\hline & Western Tanager & Piranga ludoviciana & $x$ & $x$ & $x$ & $\mathrm{x}$ & $x$ \\
\hline & Western Wood-peewee & Contopus sordidulus & & & & $\mathrm{X}$ & $\mathrm{X}$ \\
\hline & White-crowned Sparrow & Zonotrichia leucophrys & $x$ & $x$ & $\mathrm{x}$ & & \\
\hline & Willow Flycatcher & Empidonax traillii brewsteri & & $x$ & & & \\
\hline & Wilson's Warbler & Cardellina pusilla & $x$ & $\mathrm{X}$ & & & \\
\hline & Yellow-breasted Chat & Icteria virens & $x$ & $\mathrm{x}$ & & & \\
\hline & Yellow-rumped Warbler & Setophaga coronata & $x$ & $x$ & $x$ & $\mathrm{X}$ & $x$ \\
\hline
\end{tabular}




\begin{tabular}{|c|c|c|c|c|c|c|c|}
\hline & \multirow{2}{*}{\multicolumn{2}{|c|}{ Species }} & \multicolumn{5}{|c|}{ Habitat Type } \\
\hline & & & \multirow[b]{2}{*}{ Wetland } & \multirow{2}{*}{$\begin{array}{c}\text { Oak } \\
\text { Woodland }\end{array}$} & \multicolumn{3}{|c|}{ Douglas-fir Forest Seral Stage } \\
\hline & Common Name & Scientific Name & & & Early & Middle & Late \\
\hline \multirow{9}{*}{ 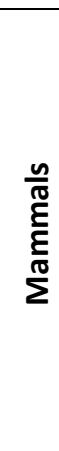 } & American beaver & Castor Canadensis & $\mathrm{x}$ & $\mathrm{x}$ & & & \\
\hline & Bobcat & Lynx rufus & $x$ & $\mathrm{x}$ & & & \\
\hline & California Ground Squirrel & Spermophilus beecheyi & & $x$ & & & \\
\hline & Columbian black-tailed Deer & Odocoileus hemionus columbianus & $x$ & $\mathrm{X}$ & & & \\
\hline & Common Raccoon & Procyon lotor & $x$ & $\mathrm{x}$ & & & \\
\hline & Coyote & Canis latrans & $x$ & $x$ & & & \\
\hline & Douglas Squirrel & Tamiasciurus douglasii & & $\mathrm{x}$ & $\mathrm{x}$ & $x$ & $\mathrm{X}$ \\
\hline & Western Gray Squirrel & Sciurus griseus & & $\mathrm{X}$ & & & \\
\hline & Long-tailed Weasel & Mustela frenata & $x$ & $\mathrm{x}$ & & & \\
\hline \multirow{2}{*}{\multicolumn{3}{|c|}{$\begin{array}{r}\text { Total Number of Species: } \\
\text { Number of Species Found in both Wetland and Oak Woodland Habitats: }\end{array}$}} & 76 & 78 & 16 & 33 & 30 \\
\hline & & & & 70 & & & \\
\hline \multicolumn{3}{|c|}{ Number of Species Found in All Douglas-fir Seral Stages: } & & & \multicolumn{3}{|c|}{13} \\
\hline \multicolumn{3}{|c|}{ Number of Species Found in ALL Habitats: } & \multicolumn{5}{|c|}{11} \\
\hline
\end{tabular}




\section{Methods}

Field Observations and Data Collection

Overview

Thirteen site visits were conducted from March 21, 2017 to August 17, 2017. The primary project area focused on 61 acres on the west end of the section south of SW Dixon Mill Rd. (Project Area Map, Appendix B). However, observations were made outside this area where possible via the fire road that extends into the potential landslide area to the east.

The data collected during all visits included GPS coordinates, field notes, and photo documentation where possible. Field notes included observations of changes to hydrologic conditions, animals present, plant community structure, etc. Using a Garmin eTrex GPS unit, coordinates were collected for a variety of features. GPS coordinates collected include the path traversed ("tracks"), pool edges and saturation zones associated with wetlands, location of spring head, invasive species areas of concentration/presence, potentially unidentified OWO, and human use/dumping sites (e.g. tires).

\section{Hydrologic Features}

To identify potential wetland habitat, surveys began on March $21^{\text {st }}, 21$ days after the beginning of the growing season, in order to identify saturation zones congruent with the wetland identification criteria discussed previously (Wetland Habitat Value and Characteristics, page 6). Hydrologic conditions were the focus of site visits from March 21, 2017 to May 1, 2017, although all field observations were recorded as well. To locate the wetland and any other water features, I began by following the path of water from the culvert at the west end of Dixon Mill Rd. and collected GPS data for the locations of small pools, saturated areas, and larger pool boundaries, all of which would ultimately be included in the wetland boundary. The seasonal spring was located by following the saturated area eastward and then the sound of trickling water. The area was examined 
to determine the locations of the spring head depending on the seasonally shifting water table levels; the highest level of apparent spring activity (evidenced by soil erosion) was used to mark the head of the spring on the maps (see Project Area, Current Habitat Distribution, and/or Recommended Habitat Distribution maps, Appendix B). During these visits, I also assessed and collected coordinates to aid in mapping invasive species and field notes and photos of any flowering plants that would not persist into the summer's plant surveys, as well as animals/insects observed in the area.

\section{Botanical Surveys}

Botanical surveys were performed from August 1, 2017 to August 17, 2017. Because the purpose was to create a comprehensive species list, not a quantitative assessment of species densities or a diversity index, randomized sampling methods were not suitable. Instead, "intuitive controlled surveys" similar to the method used for locating sensitive plant species in the Green Mountain Project EIS (USDA Forest Service, 2016) were applied to the plant surveys. This was accomplished by incorporating plant surveys in plots with plant ID's collected along the paths between plots (when previously unidentified plants were found). Eleven plots ( 30 feet in diameter) were selected in the field where plant diversity was abundant and were distributed over 61 acres of the Primary Project Area ( 8 plots) and Forest Road (3 plots) to capture the variety of species present in all habitat (Plant Survey Map in Appendix B). Some plots were placed on the edges of habitats to capture the greatest diversity in these areas. Habitat descriptions were recorded for all plots and used to define the habitats where each species was found. However, because the goal was an inventory, species were recorded only once in each habitat type, not repeatedly if found in multiple plots. All forbs and hardwood plants in each plot were either identified in the field using my existing botanical knowledge as well as Plants of the Pacific Northwest Coast (Pojar \& MacKinnon, 1994), or through extensive photo documentation using the multiple sources described below. Grasses were not the project priority and therefore were excluded. Plant surveys were 
suspended when the same plants were being identified repeatedly and no new species were being found.

A spreadsheet was created (Appendix A) including family, genus, species, authority, native status, common name, habitat type(s) the plant was observed in, and wetland status for all identified plants (those identified in the field and those later identified by photo). The USDA Plants Database was used to determine native and wetland status; the Oregon Department of Agriculture's online database for noxious weeds (Oregon Department of Agriculture, 2018) was consulted for each plant to identify plants currently listed as a noxious weed in Oregon.

\section{Data Processing and Analysis}

\section{Precipitation Analysis}

In order to evaluate if the soil saturation observed in March 2017 was typical for the area and acceptable for defining the wetland boundary, it is important to compare the rainy season precipitation rates that would affect soil saturation from year to year.

Precipitation data is not available for the park directly. To assess hydrologic inputs,

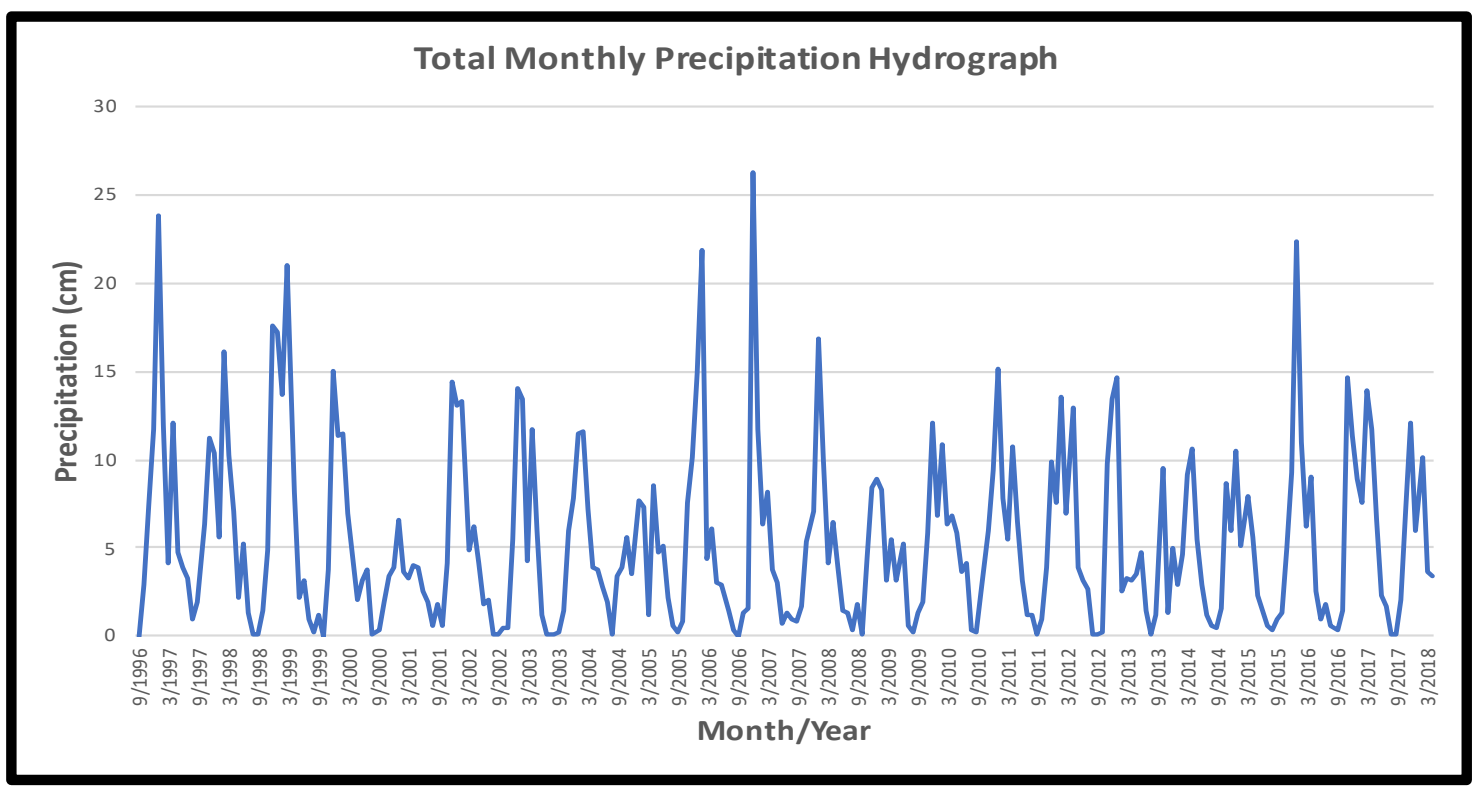

Figure 2: Hydrograph of total monthly precipitation data, daily averages from 9 weather stations distributed around the park within a 25-mile radius of the project area were summed for total monthly precipitation. The variability in monthly precipitation and oscillation between wet winters and drier summers is indicative to the area. 
precipitation data from NOAA's National Centers for Environmental Information was downloaded and analyzed to evaluate precipitation conditions for the area surrounding the park, using data available for zip codes 97123 and 97119 from 9/1/96 to 3/23/18 (see map of rain gauge locations in Appendix B). All gauges used for this analysis were within 25 miles of the project area in order to capture localized precipitation trends. The daily precipitation values from the 9 monitoring stations were averaged together; these daily averages were then summed to find total monthly precipitation values which were used to create a hydrograph for the local precipitation (Figure 2).

Because winter is the rainy season for the PNW and those months are most likely to contribute to the amount of soil saturation observed in March, I compared the average precipitation values for November through March for each year from 1997 - 2018. While the average rainy season precipitation varies from year to year and the occasional dry year may occur (e.g. 2001), 2017 was within the typical precipitation range recorded in the area for the last 20 years (Figure 3). This information was used to validate the field observations used to establish a reasonable wetland boundary.

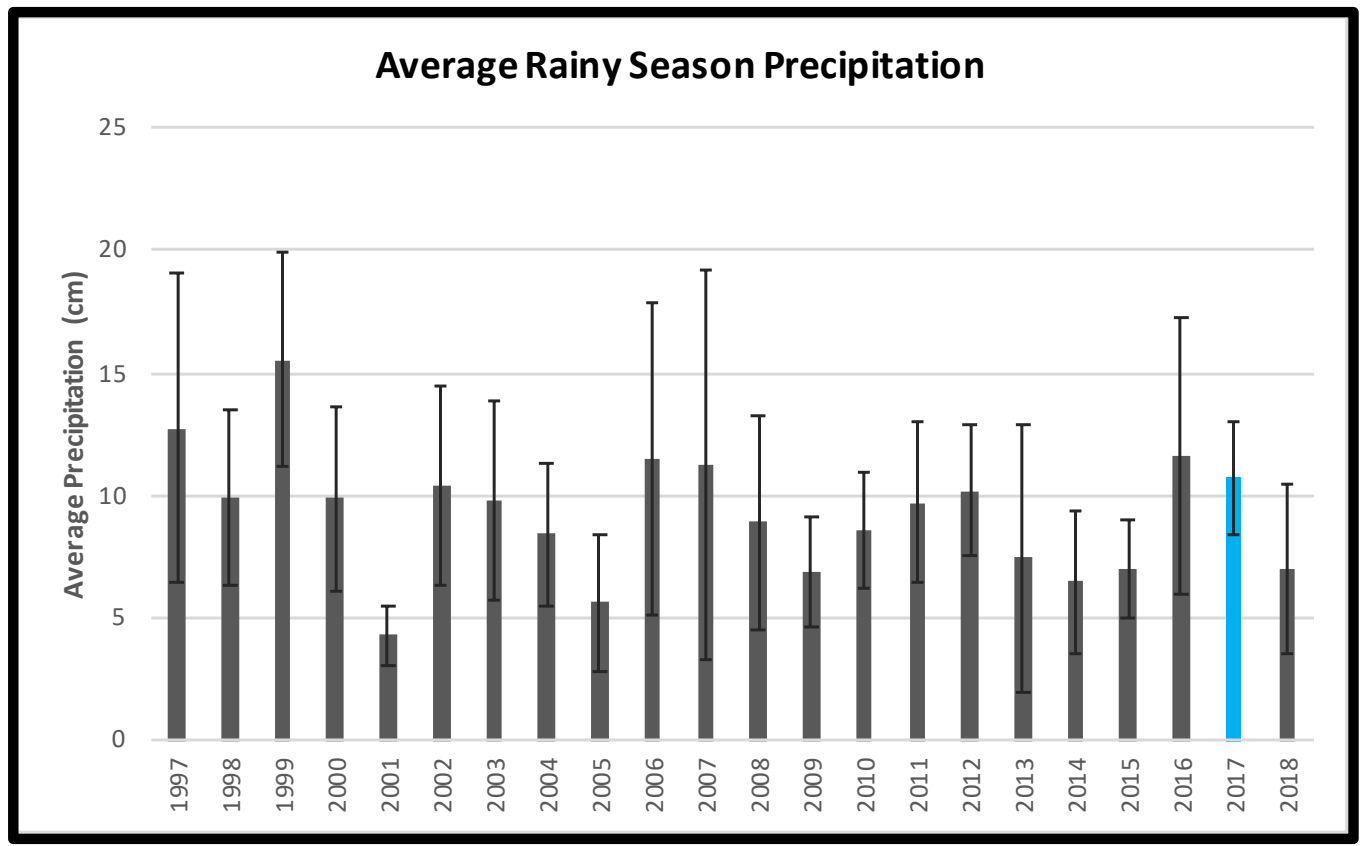

Figure 3: Average rainy season precipitation bar graph from 1997 to 2018. Error bars represent one standard deviation of the mean for each rainy season. The average precipitation for 2017 is highlighted in blue and is within the typical range for most years. 


\section{Photo Identification}

Unknown plant photos were grouped by species and plot, then identified using a variety of botanical resources such as the USDA Plants Database (USDA, NRCS, 2018), the Burke Herbarium Image Collection (Burke Museum, 2018), and Plants of the Pacific Northwest Coast (Pojar \& MacKinnon, 1994). Where sufficient detail was not available (e.g. no fruit or flowers), plants were identified to genus level only. Insect photos were identified through www.bugguide.net hosted by lowa State University's Entomology Department.

\section{Map Creation}

Maps (Appendix B) were created using ArcGIS and the GPS data collected on a Garmin eTrex 30 using coordinate system WGS 84 . This data consisted of both tracks and waypoints tagged with notes describing the feature being marked. Tracks data and waypoints were separated into appropriate groups for mapping features (e.g. invasive species locations, wetland features, etc.). The points collected as track data were joined to create lines illustrating the path/area covered during the plant surveys. Where noxious weeds were identified between plots during the plant ID portion described above, the time stamp on the photo was matched to a corresponding coordinate in the tracks data (or plot coordinates when within a plot). The coordinates provided by NOAA for the various rain gauge locations were used to map the distribution of gauge locations used for the hydrologic analysis described above. Habitat boundaries were created using a combination of waypoint GPS data, a topological layer available through ArcGIS, satellite imagery, and field notes. 


\section{Existing Conditions}

$\underline{\text { Soils }}$

Soils form the foundations for all habitat types and fundamentally influence the type of vegetation and hydrologic conditions that ultimately define these habitats. The CRNP soils are all of the Alfisol soil order, which are silty loams that develop under forest canopies with moderate leaching, high native fertility, and sensitivity to erosion in areas lacking vegetation (Metro, 2014). Although more than 60\% of the soils in CRNP are of the Laurelwood series, the soils in the project area are primarily Saum series with slopes ranging from 2\% - 60\% (Metro, 2014). Metro previously determined that the primary landslide area is located where these two geographic (soil) units meet and the geotechnical report should be consulted when planning any soil disturbing activities in the park (Metro, 2014). Additionally, Saum series soils are characterized as very deep (up to 68 inches, usually greater than 60 inches to the basalt parent material), well drained soils formed in areas that have a history of mass movement with precipitation resulting in variable rates of surface runoff and permeability (National Cooperative Soil Survey, 2006c). During field visits it was observed that on the hill tops, soil was sensitive to compaction under foot and tended toward instability on the sides of the slopes, consistent with the characteristics of the Saum soil series. These conditions persisted while the soil at the base of the slope was saturated. Later in the season, as the soils drained and the Saum series soils at the base were no longer saturated, the soil stabilized and was less subject to compaction or slippage under foot.

The primary area for the wetland habitat (further discussed below) also corresponds with a small area of Cove series soil (Metro, 2014) which is formed from alluvium in flood plains and are "very deep, poorly and very poorly drained" soils (National Cooperative Soil Survey, 2006a). Portions of this soil type remained saturated (with some pooling) for the longest periods, indicative of their poorly drained characteristic. 
Soil conditions were not assessed in the field for the area in or near the potential landslide zone, although they have previously been categorized as primarily Laurelwood series with slopes ranging from $3-30 \%$ (Metro, 2014) with moderate permeability and slow to rapid runoff (National Cooperative Soil Survey, 2006c) making erosion a potential concern. However, a survey of the fire road that cuts through this landslide prone portion found deepening crevices cutting across the road where water runoff has been eroding away the delicate Alfisol soil as it moves down the slope and across the old fire road. From personal communication with Kate Holleran at Metro, it is understood that the fire road accessibility is not intended to be maintained and that some of these cuts may have been previously established as intentional drainage pathways. Herbaceous vegetation and grasses have begun to colonize these cuts, which may help to minimize further erosion.

\section{Riparian Forest Area}

Streams Outside Primary Project Area

The streams on the east end of the unit, in the potential landslide zone, were dry early in the season and are deeply incised. The channels are relatively straight and there are abundant small boulders and sword ferns in these stream bed; some woody debris was also observed in the stream channels (Figure 4). It is likely that the deep incision caused by erosion of the soft soils was the result of previous land use that involved clearing of the vegetation for orchards and/or the current Douglas-

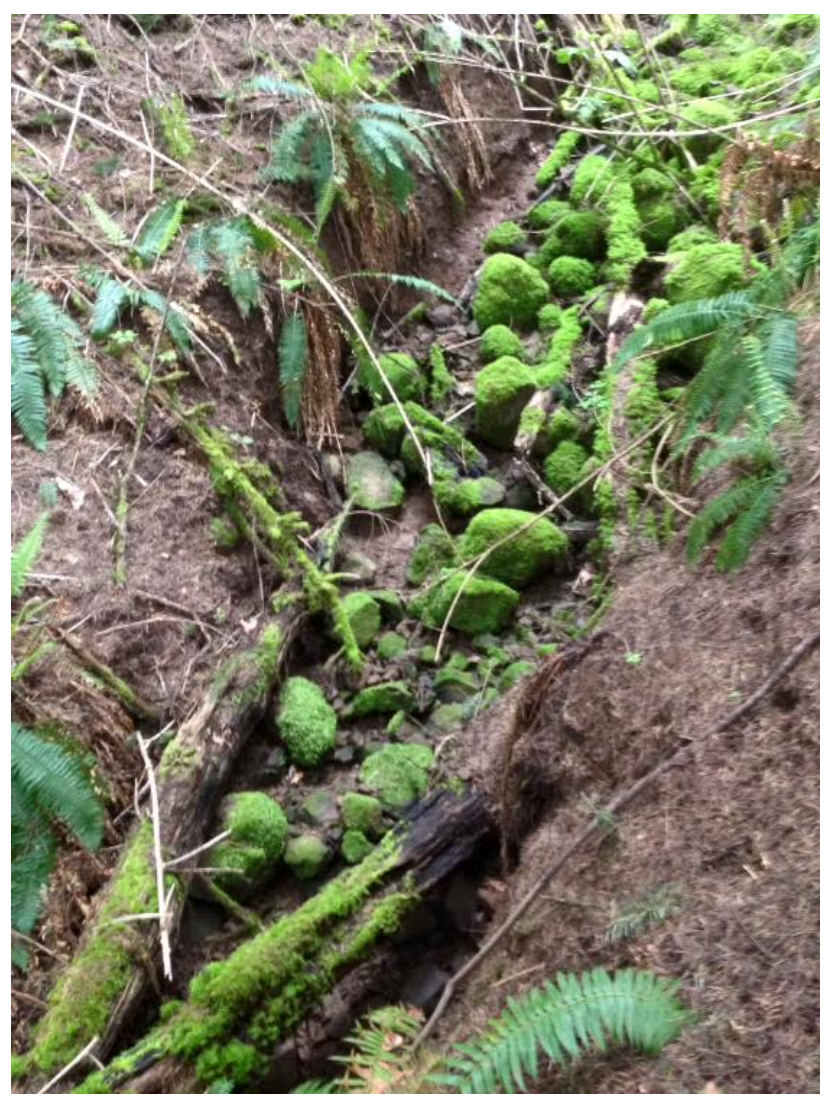

Figure 4: Stream on eastern end of fire road, in the potential landslide zone. Abundant small boulders and woody debris present in deeply incised stream. 
fir tree farm (Kate Holleran, personal communication).

Streams Inside the Primary Project Area The streams in this section of the park are seasonal, first order tributaries to Hill Creek (Metro, 2014). However, there is no clear stream path at the base of the slopes and current satellite imagery available through Google Maps shows that the previously mapped path no longer directly connects to Hill Creek, but rather appears to terminate in a small retention pond to the south of the park. The streams and seasonal pools within the park may support amphibians, but not fish. Because these streams originate in a natural area, the potential water pollution sources that may affect wildlife in the park will primarily be from atmospheric deposition, sediment erosion, and pesticides (both legacy and current applications for invasive species treatments).

A small amount of riparian forest habitat begins at the pipe culvert on

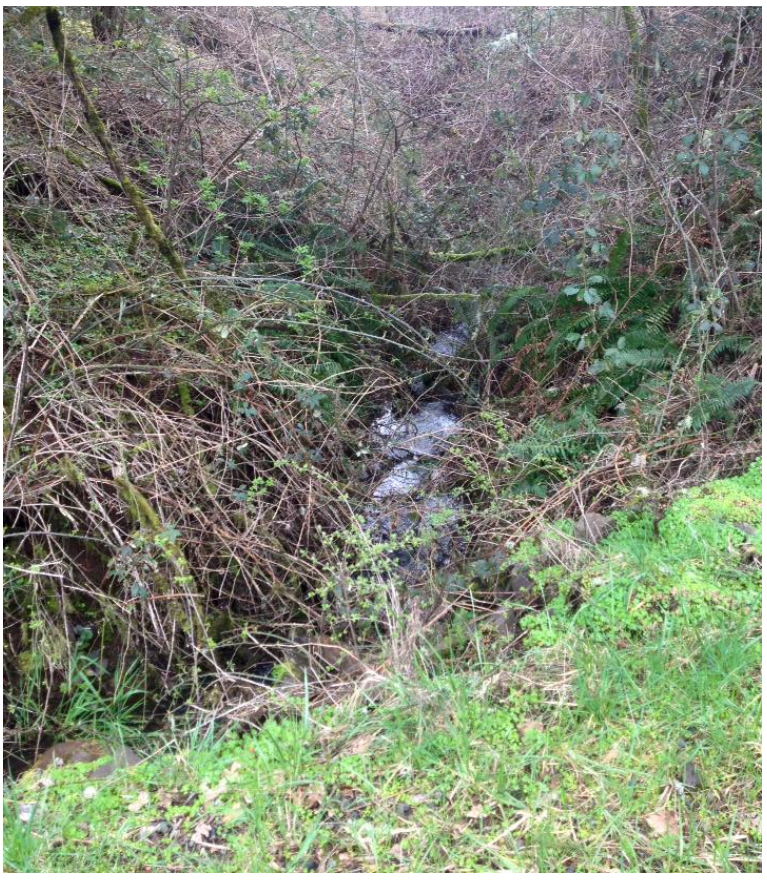

Figure 6: Western-most stream head at Dixon Mill Rd. culvert (visible in bottom left corner). Shows deep incision of soil and infestation of blackberry. Photo taken mid-March 2017 before blackberry has leaves have form on many of the vines.

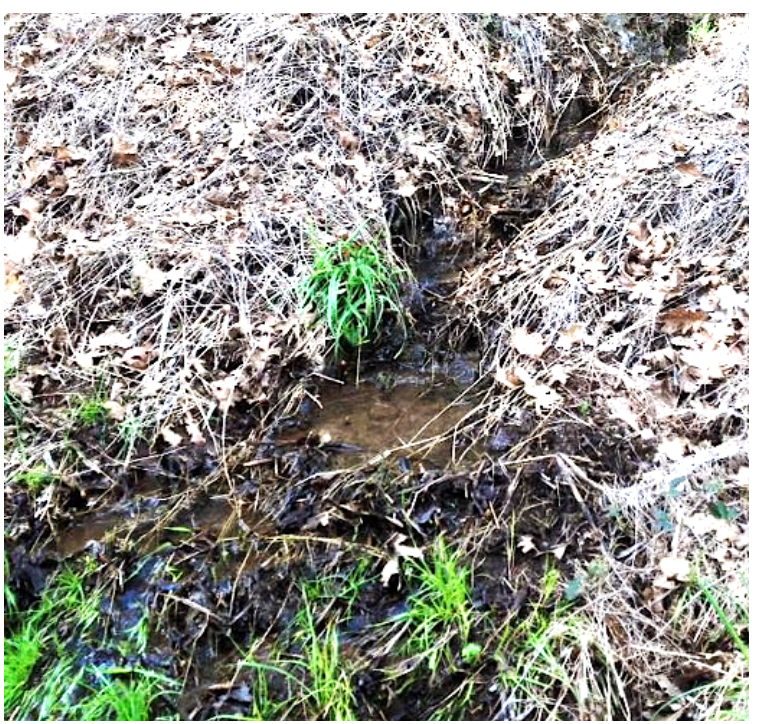

Figure 6: Western-most stream at the base of the slope. Reduction of incising is visible as well as influence of dead grass on path of rivulets that disperse at the base of the slope. 
the west end of SW Dixon Mill Rd. This stream connects the old mill pond on the north side of SW Dixon Mill Rd. to the wetlands at the base of the slope. Along this creek path, the soil has eroded away (typical to the soil type) and incised creating a deep cut into the slope of the hillside, in some place greater than 5 feet. The stream is densely infested with blackberry (Figure 5), preventing complete traversing of the creek path. Near the base of the slope, the incising gradually reduces until there is no clear stream cut and the water begins to spread out (Figure 6), splitting into several progressively smaller rivulets, dispersing

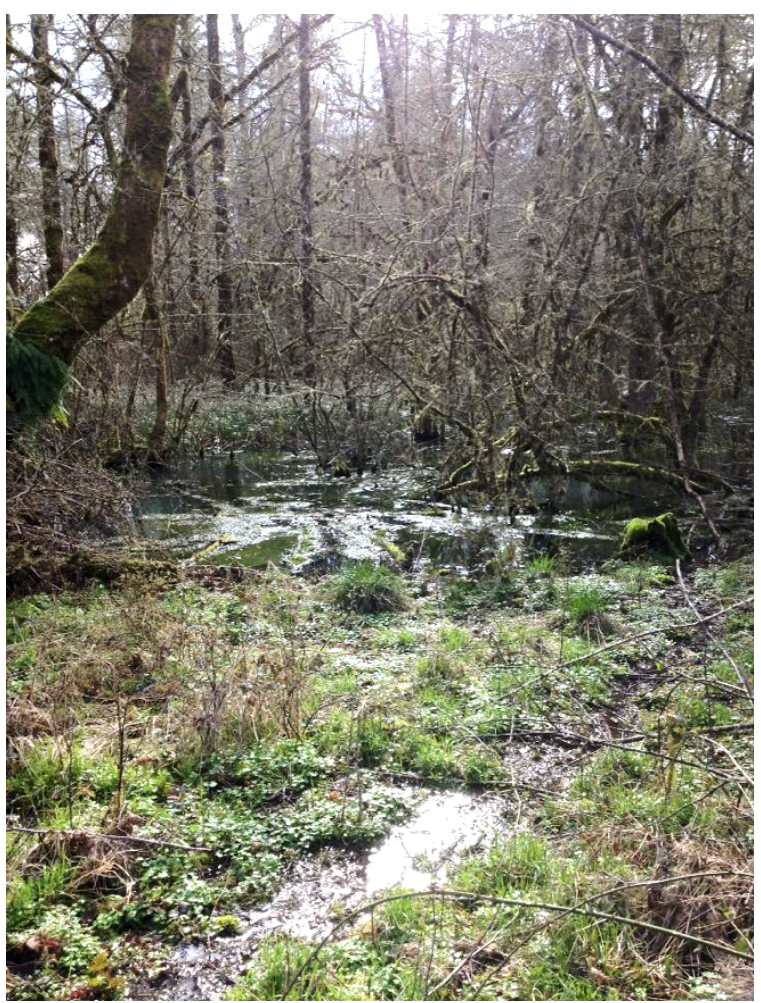

Figure 7: One of several rivulets that disperse water from the western-most stream at the base of the slope into the wetland visible in the background.

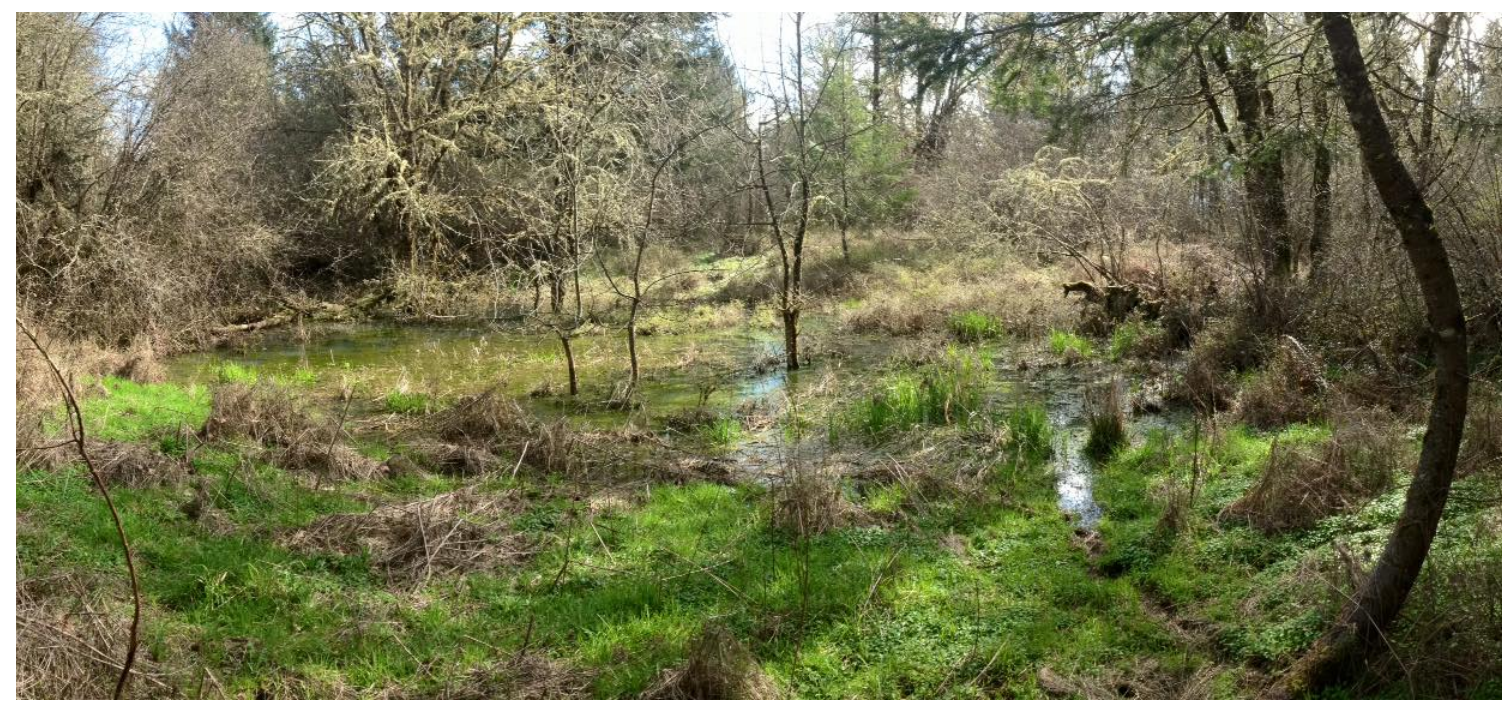

Figure 8: One of several shallow pools in the wetland area with its tributary rivulet. Some of the grass mounds from last season are visible as well as the broad expanse of new grass and abundant shining geranium ground cover visible in the lower right corner. 
water across the slope bottom into the wetland area (Figures $7 \& 8$ ).

About halfway up the slope, in the section just east of the $90^{\circ}$ turn in SW Poppy Dr., there is a seasonal spring. The soil erosion caused by the moving water has exposed large cobbles/small boulders along the upper position of the path of the spring. The spring head appears to shift from mid to bottom slope (evidenced by erosion) depending on the groundwater level. These features are easy to see early in the season but later become obscured by the dense infestation of reed canary grass (Phalaris arundinaceae) that surrounds the spring. Unlike the pooling found in the area directly west of the spring (north of SW Poppy Dr.), there is no restriction to the water flow in this section and the stream quickly spreads out over the saturated soil before it leaves the park boundary. The soil associated with the spring remained saturated at least 20 days into the growing season, though there were no pools associated with this area. The soil quickly dried when the spring stopped flowing, most likely due to the lack of pools that could retain water further into the season, and the well-drained Saul series soil type. For this reason, the path of the spring was designated riparian forest in the Current Habitat Distribution map (Appendix B).

The riparian forest habitat in the primary project area consists of $\sim 9.5$ acres, although a portion of this habitat also is considered part of the seasonal wetland area (also $\sim 9.5$ acres) designated on the Current Habitat Distribution map (Appendix B).

\section{Developing Seasonal Wetland}

In April, the water's path appeared influenced by the large mounds of dead reed canary grass from the season prior (Figure 8). Horsetail buds (Equisetum telmatiea) were popping up in the shallowest parts of the stream and surrounding saturated soil between the grass mounds (Figure 9). Later in the season, the competition for space between horsetail and canary grass is more apparent, with horsetail currently maintaining a stronghold at the base of the slope, but canary grass dominating most of the available space, both sun and shade, deeper into the wetland section 
The plant community shifts from the top of the slope to the bottom. On the slope north of the wetland area and down to the southern park boundary, the community transitions to mixed hardwoods with numerous Oregon white oaks (Quercus garryana), bigleaf maple (Acer macrophyllum), and Oregon ash (Fraxinus latifolia), as well as blue elderberry (Sambucus nigra ssp cerulea), beaked hazelnut (Corylus cornuta), Pacific ninebark (Physocarpus capitatus), and oceanspray (Holodiscus discolor). As tree diversity increases, a patchy, multi-layered canopy structure is created that

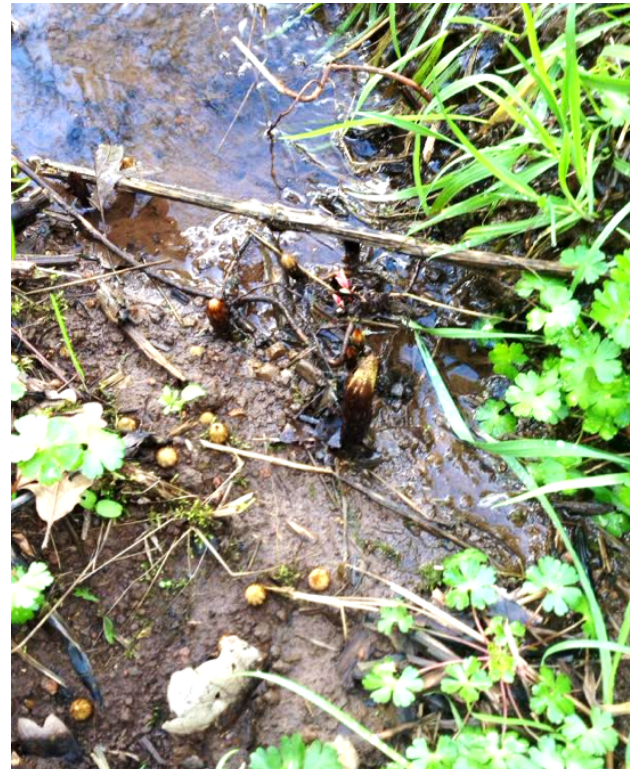

Figure 8: Horsetail buds in rivulets and saturated soil at the base of the slope.

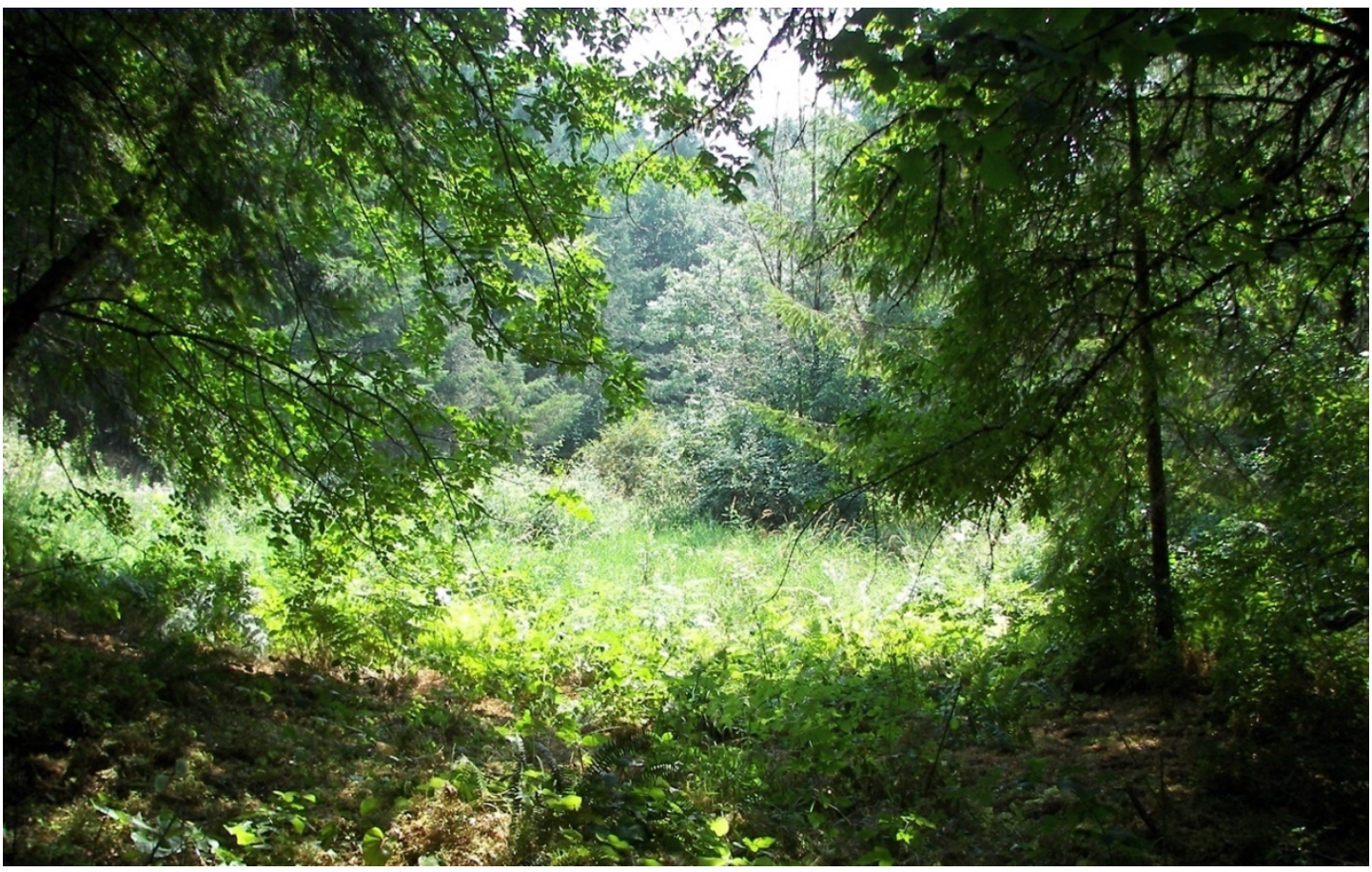

Figure 7: Example of patchwork of habitat, from the closed mixed hardwood canopy with sparse understory to open grassy areas to the Douglas-fir forest of the eastern end of the unit visible in the background. 
incorporates open areas, dense patches of shrubs, and a diverse understory of herbaceous plants with shifting dominant ground cover (Figure 10). This patchwork of conifer, hardwood, shrub, and open canopy grassy areas extends beyond the wetland area and spring, into the potential landslide area to the east.

In the lowest elevation areas on the west end of the unit, from the base of the slope to SW Poppy Dr., some portions of the soil remained saturated through the end of the summer, though pools suitable for water fowl were gone by August in 2017. Several
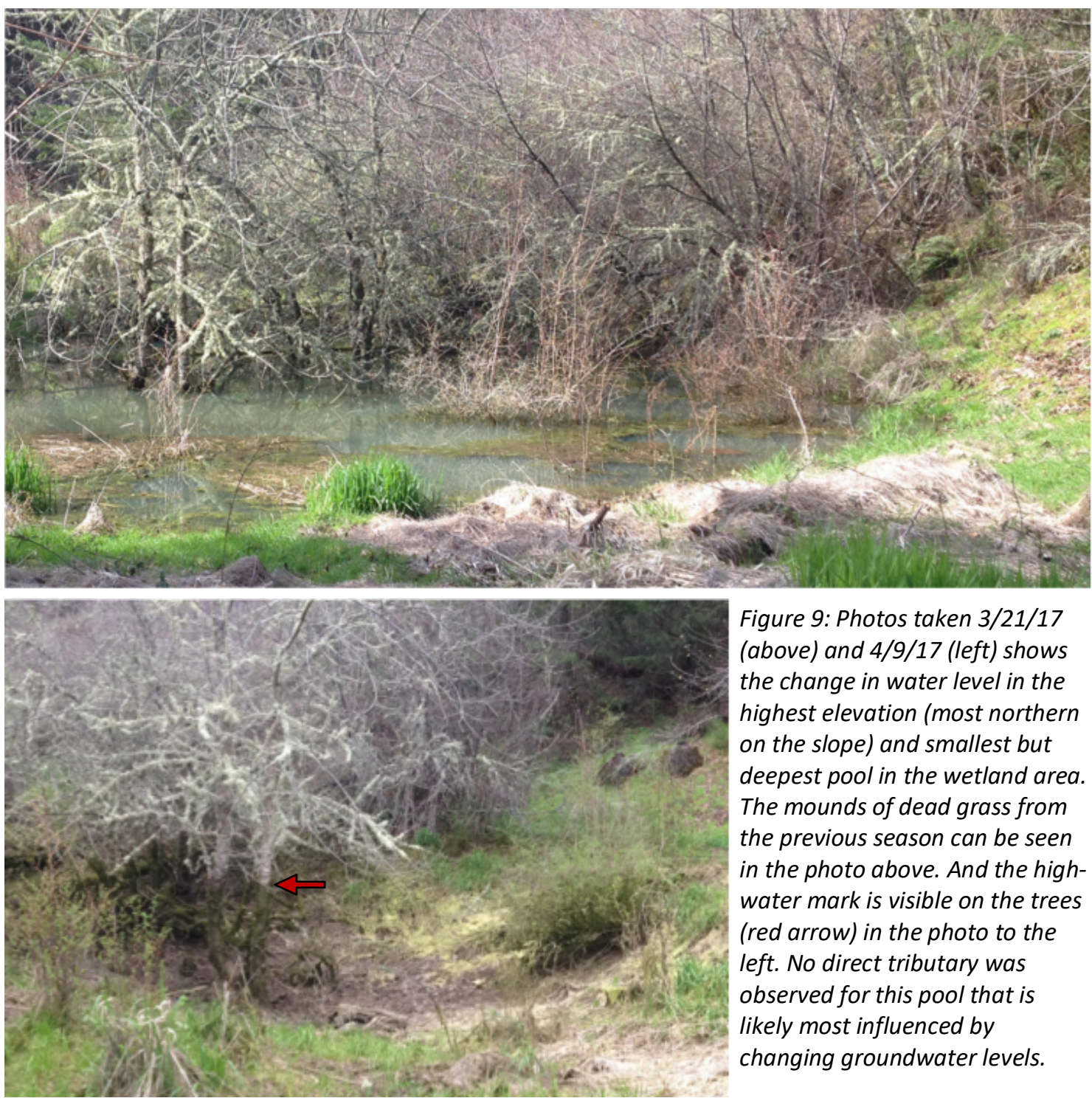

Figure 9: Photos taken 3/21/17 (above) and 4/9/17 (left) shows the change in water level in the highest elevation (most northern on the slope) and smallest but deepest pool in the wetland area. The mounds of dead grass from the previous season can be seen in the photo above. And the highwater mark is visible on the trees (red arrow) in the photo to the left. No direct tributary was observed for this pool that is likely most influenced by changing groundwater levels. 
pools of varying sizes and depths (Figures 7, 8, \& 11) provide wildlife habitat; ducks and frogs were observed utilizing the area. Several downed trees in the pool interiors appear to be the result of windthrow (Figure 12). They retain their large root balls, toppling with their roots intact, likely resulting from reduced shear strength of the seasonally saturated soils (Edmonds et al, 2011, pg 180). This may be a relatively new condition related to recent changes in inundation/pooling due to the restricted hydrologic conditions resulting from the installation of SW Poppy Dr. and its drainage culvert. Some form of root disease has not been ruled out at this

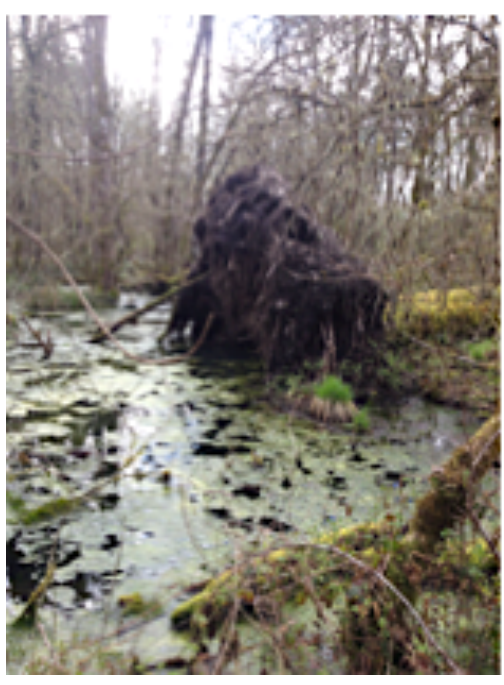

Figure 10: A downed tree and root mass in the saturated wetland area, most likely the result of windthrow due to reduced shear strength of the saturated soil. time. However, the low quantity and location of these downed trees is not indicative of the typical spread of a root disease through the soil matrix.

\section{Oak Woodland Forest}

Several pockets of Oak dominated woodlands exist in the unit with strong potential for management/restoration efforts. White oaks are known to grow in a wide variety of soil and hydrologic conditions (Wilken, 2000; Niemiec, 1995), which is also seen in this unit where they are found along the entire slope gradient from the drier hill tops to the saturated wetland areas and across several different soil types. Because the hydrology is seasonally driven, there is great overlap in the oak woodland habitat with the wetland and riparian forest zones. For this reason, the area designated as oak woodland habitat ( 33 acres) includes the 9.5 acres of current wetland, as well as the 9.5 acres of riparian forest that overlaps both the wetlands and the oak woodland habitat areas (Current Habitat Distribution map, Appendix B). It should also be noted that there are several pockets of OWO in the potential landslide areas to the east as well as above the fire road that are not included in the acreage measurements found here. All the oaks observed south of SW Dixon Mill Rd., both within the primary project area and to the 
east from the fire road, were columnar in shape, indicative of oaks found in areas with high competition for light resources from either inter- or intra-species competition (Thompson, 2007; Peter \& Harrington, 2002) (Figure 13).

Where the conifers have not yet encroached, the associated woody vegetation is dominated by the community of mixed hardwoods described in the previous section (page 25). However, even though there has previously been some oak-release
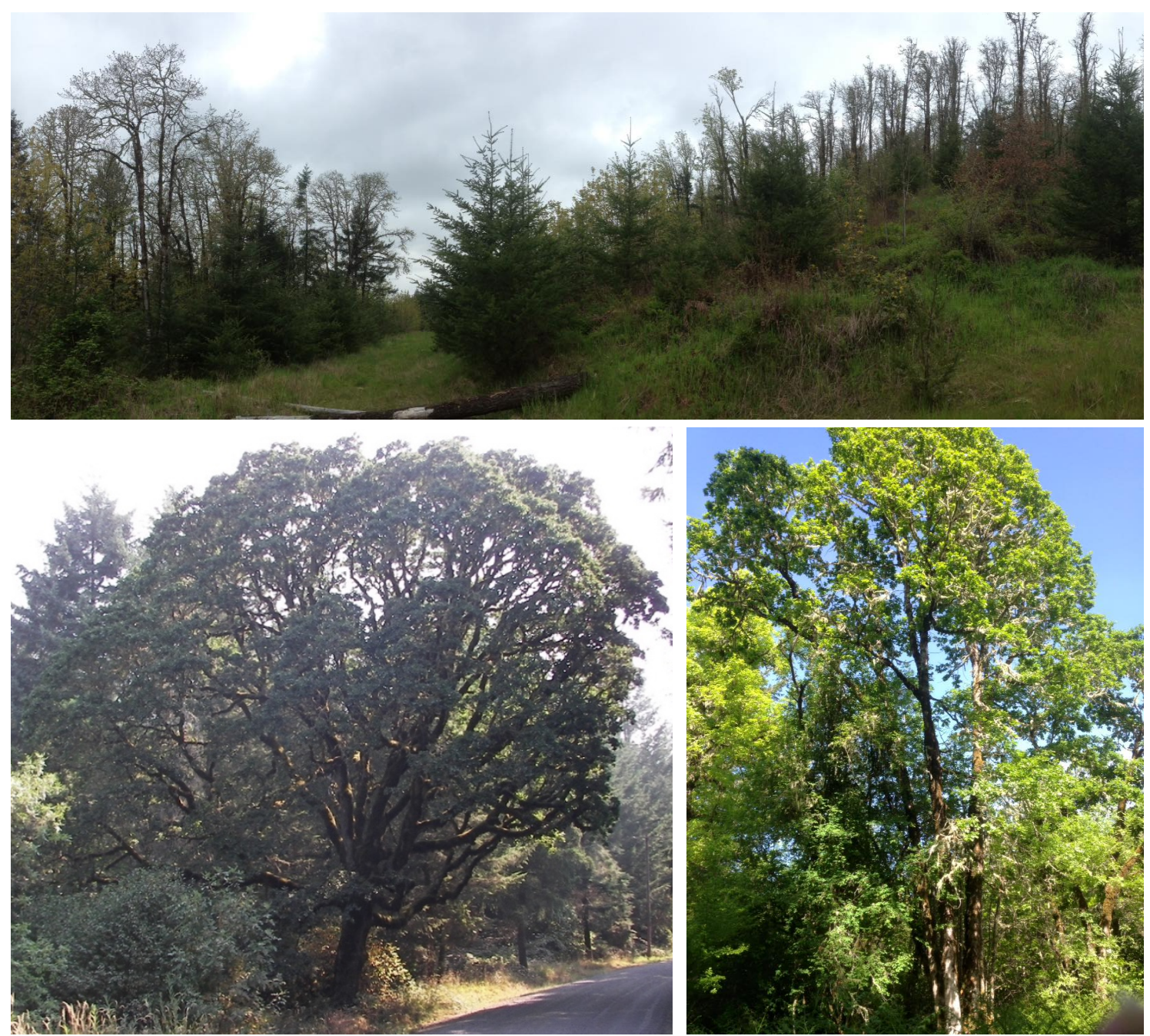

Figure 11: Examples of oak crown shapes and related competition found in the park. Clockwise from the top: closely spaced columnar shaped oaks along the forest road with encroaching baby conifers in the understory; a columnar oak competing for resources with the adjacent hardwoods, located near the wetland area within the primary project area; compared to the broad crown of the large white oak just north of SW Dixon Mill Rd., adjacent to the old mill pond (just outside the project area), where competition for light is minimal. 
treatment applied by Metro, these hardwood trees and bushes are sometimes within the recommended clearing radius for conifers. The oaks on the west end, associated with the wetland and Riparian forest habitats, are easily accessed and applying silviculture treatments would be easiest with minimal soil disturbance in the dry season.

There are numerous gaps in this section where grasses, bracken fern (Pteridium aquilinum), and invasive/non-native species like Himalayan blackberry (Rubus ameniacus), both Canada and bull thistle (Cirsium arvense and Cirsium vulgare respectively), and scot's broom (Cytisus scoparius) compete for the open sunny areas, each species often creating compact areas of species populations (Figure 14). The oaks situated north of the fire road were already included in the Douglas-fir thinning plans for the ridge top, but there are also oaks south of the fire road (Figure 14). This section may be too steep and unstable for management activities and should be considered in conjunction with Metro's previous technical geological survey (Metro, 2014). However, the brush was relatively dense and further accumulation may create hazardous ladder fuels if no treatments are applied.

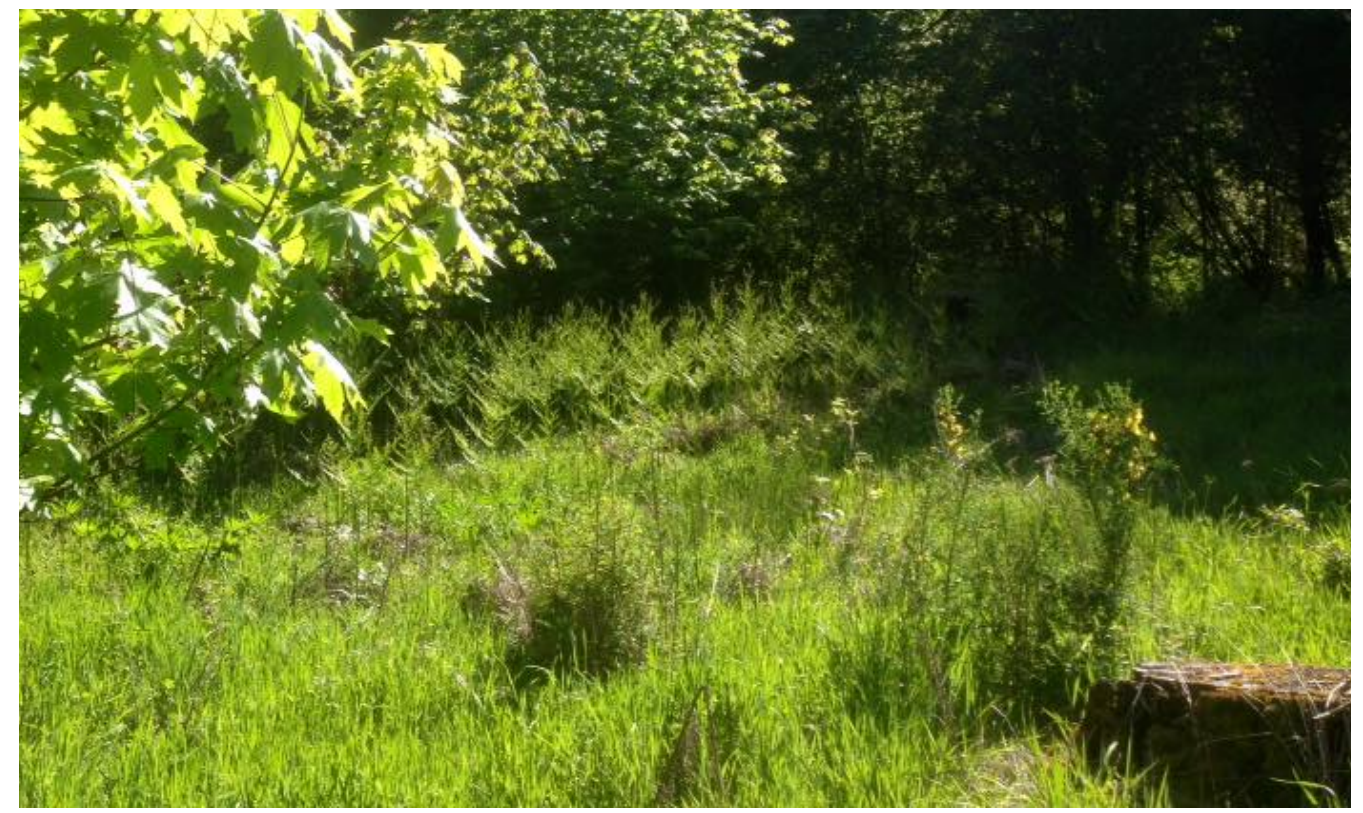

Figure 12: Example of species groups competing for resources in the open areas with bracken fern groups together in the middle/back and grasses dominating the foreground with scot's broom moving to compete with the small snowberry in the center. 


\section{Douglas-fir Forest}

A uniform single canopy of Douglas-fir forest is on the hilltop and along the western boundary, with sparse understory due to the previous management of the tree farm that used herbicides to minimize plant growth that would inhibit future logging (Metro, 2014) as well as the shaded conditions due to the high stem density and closed canopy of the tree farm. The Douglas-fir forests south of the fire road and west of the landslide area are similar to these sections of plantation on the top of the slope and western end of the unit. They are mostly even aged stands with very sparse understory primarily consisting of sword fern (Polystichum munitum), the occasional snowberry (Symphoricarpus albus) or tall Oregon grape (Mahonia aquifolium) and a variety of herbaceous species such as wall-lettuce (Mycelis muralis), common nipplewort (Lapsana communis), and bedstraw (Gallum sp.). At the boundaries between the Douglas-fir forest and the oak woodland, the compositions blend as a variety of deciduous trees and bushes mix beneath the large conifers, especially at the forest edges where light availability is greatest. However, the abundance of small conifers along these edges indicate that the Douglas-fir forest habitat is, and will continue, spreading without management controls put in place to remove the fast-growing conifer seedlings.

\section{Botanical Summary}

Although the botanical species list is extensive and provides a baseline evaluation of the presence of both native and non-native species, there is the possibility that plants were either not observed or not present during the field visits (e.g. short-lived herbaceous species may not have been present during the plant surveys). Metro does not assume that a plant is necessarily absent simply because it is not listed (Kate Holleran, personal communication, 2018). The sixty (60) species identified in this project area (Botanical Species List, Appendix A) is within the range of number of species Metro has identified in other units ( $45-116$ species), but revisions to the list are expected over time. The botanical survey identified eight B designated weeds (bull thistle (Cirsium vulgare), Canada thistle (Cirsium arvense), scot's broom (Cytisus scoparius), shinning geranium 
(Geranium lucidum), ivy (Hedera sp.), St. John's wort (Hypericum perforatum), perennial sweetpea (Lathyrus latifolius), and Himalayan blackberry (Rubus ameniacus)) and one B and T designated weed (tansy ragwort (Senecio jacobaea)) (Botanical Species List, Appendix A). There are thirty native species, eleven non-native species, and ten plants that could not be identified to species level so their native status remains unknown as there were native and non-native species within the genus (Botanical Species List, Appendix A). There are fifteen species ubiquitous to all habitats in the primary project area, ten species found only in the Wetland/Riparian areas, nine species are unique to the Oak Woodlands as well as nine unique to the Douglas-fir Forest (Botanical Summary Table, Appendix A). Fourteen of the species found in the Wetland/Riparian areas are either facultative, facultative wetland, or obligate wetland species with thirteen being facultative upland and six with unknown wetland status (Botanical Species Summary, Appendix A). This community assemblage may provide resilience to the system given the seasonal nature of the wetlands as well as potential shifts due to climate change. A complete assessment of the number of species that are shared between the various habitats and the wetland status of the plants found in each habitat can be explored in the Botanical Summary Table (Appendix A). Given the proximity of residential and agricultural properties, the migration of landscaping ornamental and agricultural species into the area is unlikely to cease. While the plants introduced into the area are most likely the result of animal or wind dispersal, the hydrology may cause this area to be a particularly influential vector for seeds moved by water into the surrounding neighborhoods.

Invasive Species

Wherever there is ample water and sun, especially where small trees and bushes dominate the structure, the patches of open canopy are dominated by invasive species. Most of the open areas have mixtures of reed canary grass (with the largest concentrations in the wetland area and around the spring), Queen Anne's lace (Daucus carota), Himalayan blackberry (Rubus ameniacus), scot's broom (Cytisus scoparius), and 
thistle (Cirsium sp.) While there may be native thistles in the unit, the thistles found so far appear only to be the invasive Canada thistle (Cirsium arvense) and bull thistle (Cirsium vulgare). Wherever the canopy is open, both on the hillside and in the wetland area, dense patches of Canada thistle can be found. Some native species are often mixed in, like snowberry (Symphoricarpos albus), but are being outcompeted by the taller, faster growing, invasive/non-native species.

Shinning geranium (Geranium lucidum) is especially pervasive on the top of the slope across from the old mill pond, but also continues down the slope into the wetland area and to the east. It is the dominant ground cover early in the season. It was observed engulfing small shrubs and baby oaks, creating a vegetative matt that covers the affected plant and remains like a shroud even after dying off for the season. Some die back was observed on August 1, 2017, but there was some variation to the degree of die off depending on the habitat type (it persisted longest in the wettest areas).

Himalayan blackberry is ubiquitous in the unit, found in both sun and shade conditions, with several areas of concentration as well as random individuals appearing throughout. Coordinates were gathered where infestations were found (Appendix B, Invasive Species Distribution), such as a the $\sim 10$ foot clump

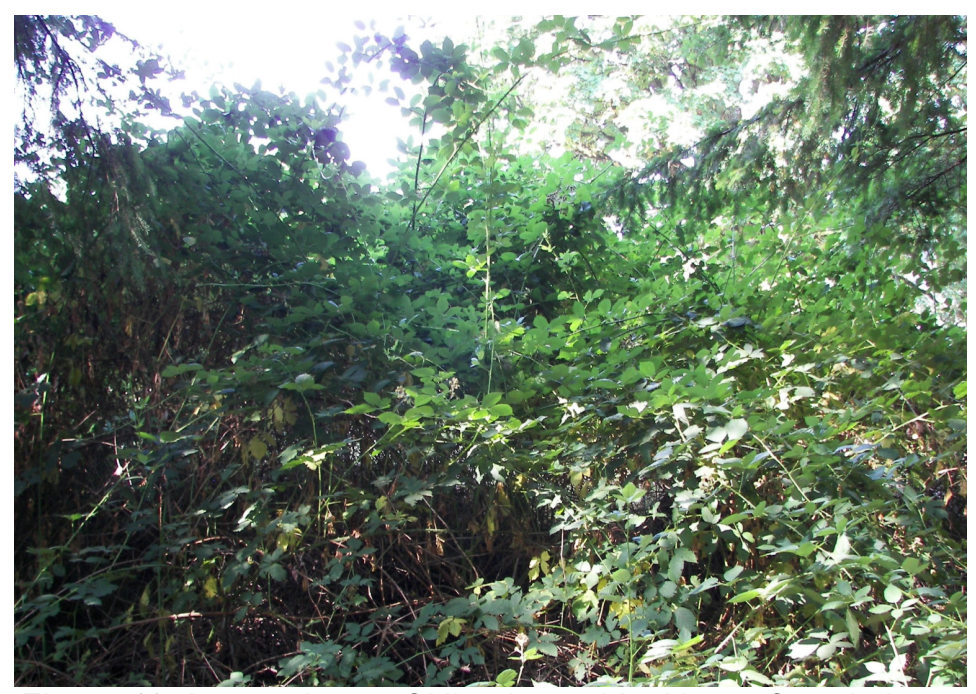

Figure 13: Large clump of Himalayan blackberry found along the western park boundary fence, approximately 10 feet in diameter. Photo taken 8/8/17.

located along the western boundary fence (Figure 15). Ivy (Hedera sp.) is similarly ubiquitous with clumps along the fire road and individuals found in the understory of all the habitat types. English holly (Ilex aquifolium) was found several times associated with 
denser conifer understory, often in conjunction with blackberry. Scot's broom (Cytisus scoparius) was found sporadically throughout the unit with several larger plants along the fire road. Given the aggressive nature of this plant, it is likely to take over large areas if individuals are left untreated and aloud to create a formidable seed bank. The largest tansy ragwort (Senecio jacobaea) was found along the fire road, though smaller plants were also found in the understory of the oak woodland habitat.

\section{Wildlife}

Animals observed throughout the unit during site visits include:

- Mallard duck (Anas platyrhyncos)

- Anna's hummingbird (Calypte anna)

- woodpecker (heard on at least two occasions, species unknown)

- Pacific chorus frogs (Pseudacris regilla),

- common garter snake (Thamnophis sirtalis),

- apple gall wasp (Figure 16), distinctive galls found, most likely attributable to Besbicus mirabilis based on gall location (Hollingsworth, 2010)),

- red tailed hawk (Buteo jamaicensis),

- deer (species unknown)

- banded woolly bear (the larval form of Pyrrharctia isabella, the Isabella tiger moth).

- A variety of insects (Figure 17).

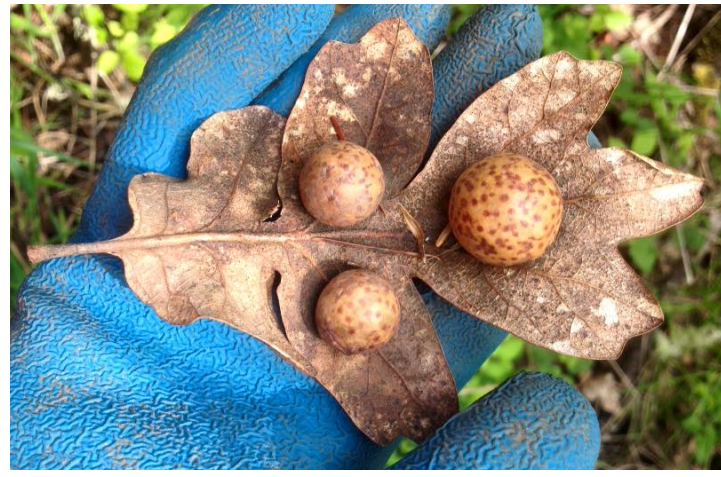

Figure 14: Apple galls found on OWO leaf, likely attributed to Besbicus mirabilis.

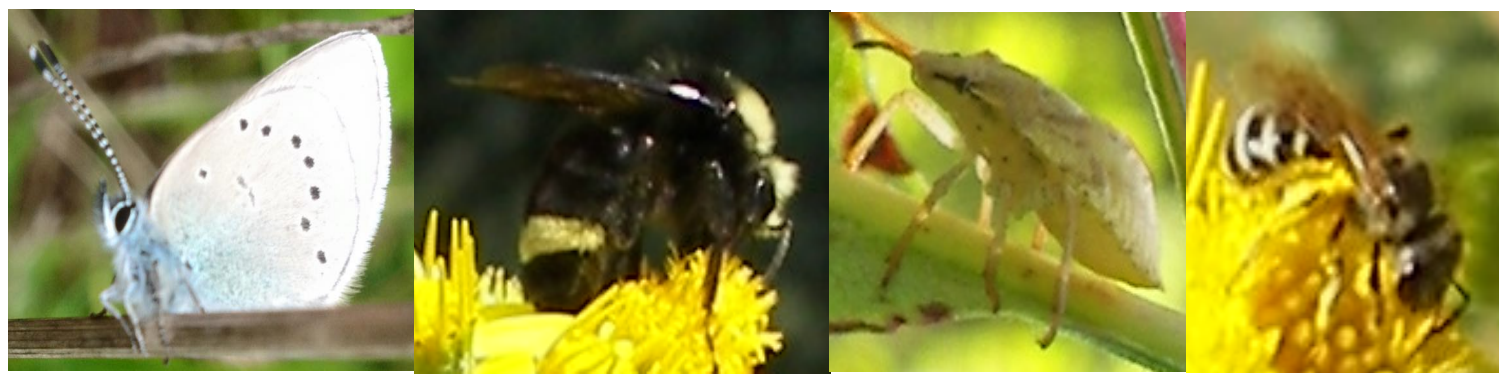

Figure 15: Examples of observed insects. From left to right: Glaucopsyche lygdamus (silvery blue, a tiny butterfly) Bombus sp. (bumble bee), unidentified stink bug nymph, Halictus ligatus (a species of sweet bee). 


\section{Human Use}

There is evidence of human use throughout the unit. Numerous sets of bones (Figure 18) may be the result of natural conditions such as predators or disease, or game hunting known to have occurred previously in the park. Tires can be found throughout the site buried under varying amounts of organic matter, suggesting that dumping tires by rolling them off the edge of Dixon Mill Road has been a long standing local practice. There is also some evidence of (unestablished but worn) hiking trails mixed with natural drainage pathways and game trails. Some trails appear to connect directly to neighboring residences, though it is unclear if they have been the sole recreational users of this section of the park.
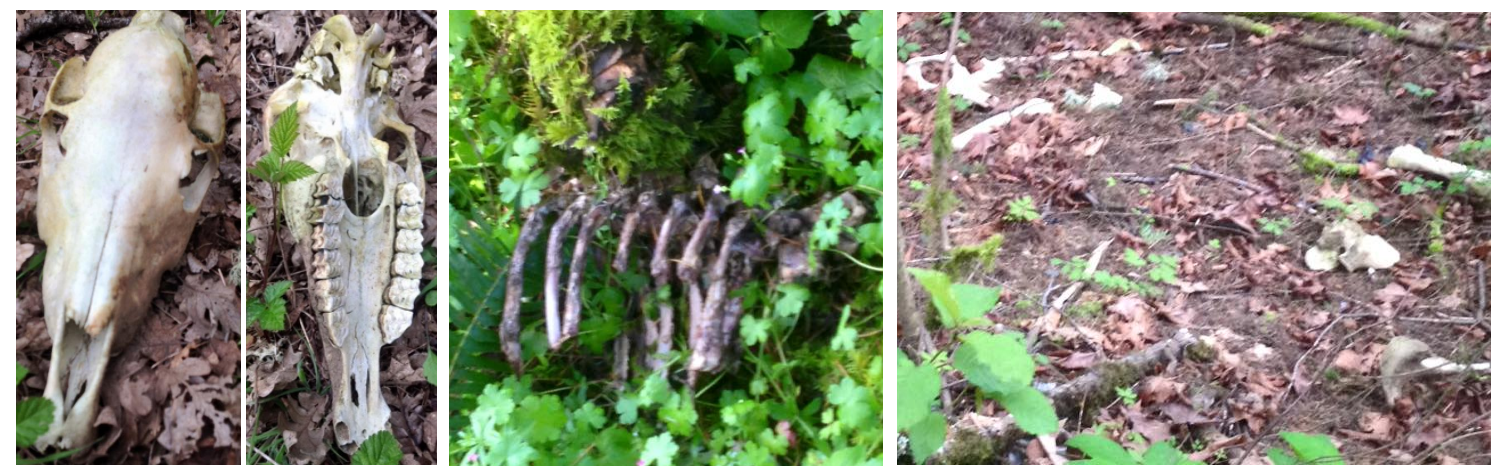

Figure 16: Examples of animal remains found in various areas of the park including (from left to right) the skull of an ungulate found on the slope, a small ribcage found in the wetland area, and a collection of bones found directly on the roadside of SW Dixon Mill Rd. 


\section{Management Recommendations}

Assumptions

For the purpose of the following recommendations, I have made a number of assumptions:

1. The park will remain under the control and protection of Metro in perpetuity and will be managed to conserve and protect valuable habitat as well as provide education and recreation opportunities to the public.

2. Climate change scenarios should be considered when making management decisions.

3. Wherever necessary, Metro will work with other agencies and community stakeholders to facilitate best practices are used to maintain or enhance habitat quality in the park. (e.g. where road maintenance is necessary but outside of Metro's jurisdiction.)

4. The restoration recommendations may not account for all economic or geotechnical elements and may therefore require additional analysis by Metro to assess viability.

\section{Setting Priorities}

I recommend four ecological priorities,

1) Increase the amount of OWO woodland habitat and enhance oak viability.

2) Enhance quality and quantity of wetland habitat

3) Invasive species management (to maintain functional community assemblages)

4) Erosion management

And one priority to meet cultural/social and educational/research values: Accessibility.

It is unreasonable to target an accurate historical structure and species assemblage for OWO savannah or woodlands in the restoration design for a number of reasons: there are persistent effects from the Douglas-fir plantation and abundant non-native species (Botanical Species List, Appendix A); the extensive use of controlled burns is 
incompatible with neighbors in such close proximity; and the changes to hydrology are developing valuable wetland habitat. Conifer encroachment and the proliferation of non-native species are inevitable. Without repeated seasonal burns the seed bank will persist for many years, as well as be replenished by the surrounding landscape. Furthermore, wetlands are such valuable habitat that altering the infrastructure to eliminate the developing wetland would be ecologically detrimental.

Therefore, I recommend focusing on ecosystem management to improve structure and function rather than strict ecological restoration using historical reference conditions (SER, 2004, Murcia et al., 2014). The overarching focus should be a resilient ecosystem that can recover from disturbance and support natural regeneration (Chazdon et al., 2017). However, as previously discussed, the patchwork habitat structure found in this unit is historically, culturally, and ecologically significant. This structure should therefore be maintained within a "novel ecosystem' approach to community assemblage. A novel ecosystem, where native and non-native species are allowed time and space to compete and assemble unique communities, can allow the development of a functional, dynamically balanced, "hybrid" system that incorporates historical and contemporary elements (Higgs, 2017; Hobbs et al., 2009). However, monitoring and controlling species with invasive characteristics, or select populations of these species, will still be necessary. Invasive characteristics include changes to soil chemistry (e.g. allelopathy) and extreme competitive advantages due to a lack of natural biological controls (e.g. predation or disease). These species can reduce biological diversity and thus inhibit resilience of the ecosystem (Huston, 1979; Downing et al., 2012, Laughlin, 2017).

OWO habitat is threatened throughout the PNW. It provides important habitat resources for a variety of animals and is historically dependent on human activities/regular disturbance (Vesely \& Tucker, 2004; Anderson, 2007; Thompson, 2007; Dunwiddie \& Bakker, 2011; Pellatt \& Gedalof, 2014; Pellat et al., 2015). Therefore, this species should be given priority when planning management activities. Because OWO 
have the capacity to tolerate a wide range of soil types and hydrology, this habitat can also persist congruently with the developing seasonal wetland.

The creation of new wetlands can be a valuable addition to habitat and water quality, both locally and on a landscape scale, and is even an acceptable option in wetland mitigation practices (Mitsch \& Gosselink, 2015; Moreno-Mateos et al., 2012; Verhoeven et al., 2006; Lautz \& Fanelli, 2008). Enhancing and supporting the development of the wetland area is preferable to removing or altering the infrastructure that has influenced its development.

In the fields of Restoration Ecology (the study of restoration) and Ecological Restoration (the practice of restoration), incorporating ecological, cultural/social, and education/research values into restoration plans is considered ideal, or even crucial, for meaningful and functional restoration projects (SER, 2004). The cultural/social and educational/research elements potentially affect ecological structure and function, both positively (e.g. volunteer labor) and negatively (e.g. invasive species introductions via seed transportation by hikers), and should be managed and designed accordingly. This recommendation section will incorporate all three values in ways that support ecosystem resilience within the hybrid, novel ecosystem, paradigm explained above.

These priorities have implications for each habitat type and interact with each other in significant ways. For example, the recommendations related to erosion control must consider impacts on habitats as well as potential impacts from accessibility. Therefore, while the recommendations for each priority have been divided into sections below, they must not be considered mutually exclusive; multiple priorities may be addressed throughout the following sections.

Increasing Oak Woodland Habitat and Enhancing Oak Viability

Oak habitat can require intensive management to maintain and restore because, with fire removed from the system, the open areas are highly susceptible to conifer 
encroachment and non-native species invasions (Devine \& Harrington, 2006, Devine \& Harrington, 2010; Hanna \& Dunn, 1996). Devine \& Harrington (2006 \& 2013) found that a "full release" strategy with a clearing radius around oaks equal to one tree height that included removal of all Douglas-firs down to a $10.0 \mathrm{~cm} \mathrm{DBH}$ yielded the best initial and long term increases to diameter growth as well as a positive impact on fecundity, likely due to the crown exposure resulting from the release strategy. Although site specific decisions may vary the clearing radius up or down, Metro has adopted a conifer clearing radius of 75 feet around OWO unless a smaller clearing is deemed necessary for habitat connectivity or other such considerations (Kate Holleran, personal communication).

In order to increase the Oak Woodland Habitat, the Douglas-fir habitat must be reduced by removing all the young conifers on the outer edge of the conifer forest. As previously noted in the existing conditions section, these habitat edges are commonly a mix of conifer and hardwoods, with the fast-growing conifers quickly overtaking the canopy. Removing these trees would increase the oak woodland habitat from $\sim 33$ to $\sim 40.5$ acres by transferring 6.5 acres of Douglas-fir habitat to the oak woodland habitat (see "Potential Oak Woodland Habitat" in the Recommended Habitat Distribution map, Appendix B). Minimizing conifer encroachment will require on-going, long-term, monitoring and maintenance as seeds are dispersed into the oak woodland habitat. However, by designating these 6.5 acres as the areas of greatest concern and management, we can minimize the regular effort required. It is possible that individual conifers will colonize the interior of the oak habitat, but these individuals can be addressed with less frequency than the encroaching boundary as lone individuals will create less shade and seed than the abundant conifers on the habitat edges. That said, the interior oak habitat should also be monitored and managed periodically to prevent groups of conifers from establishing.

Enhancing oak viability will require efforts to improve the health and regeneration (e.g. fecundity) of the oaks within the unit. Because OWO can reach heights of 50 to 120 
(max.) feet (Niemiec et al, 1995) and the full release strategy is most effective for increasing oak health and fecundity (Thompson, 2007; Devine \& Harrington, 2013), it may be advisable to increase the clearing radius to 100 feet or more wherever possible. Because these oaks are shade intolerant and sensitive to competition (Gould et al., 2011), any tree species that could over-top the oaks should be removed within this radius. Gould et al (2011) found that competition with other hardwoods was less significant than with conifers, therefore some hardwoods retained in the understory within the radius may not inhibit OWO growth and vitality. It has been found that oaks with broad crowns produce more acorns than columnar crowns (Thompson, 2007; Peter \& Harrington, 2002). While soils may influence crown shape (Niemiec et al, 1995), the openness of the canopy has a crucial impact (Devine \& Harrington, 2013) and is manageable. Intensive oak release strategies (Devine \& Harrington, 2006; Devine \& Harrington, 2013) combined with management plans that provide protection to seedlings (Devine et al., 2007; Devine \& Harrington, 2010) and mimic indigenous practices by aggressively thinning to minimize the understory surrounding the oaks (Anderson, 2007) may create the best conditions to support existing oak longevity and natural regeneration. Additionally, while there is natural regeneration of white oak seedlings and juvenile oaks dispersed throughout the unit, strategic plantings are also advised. Given their slow growth rate and the patches of destabilized soils in the saturated areas, it may be wise to strategically plant oaks in the most suitable areas rather than leaving this regeneration entirely up to chance dispersal through wildlife vectors that may also contribute to acorn predation (Fuchs et al., 2000).

\section{Enhancing Quality and Quantity of Wetland Habitat}

It is important to set appropriate/attainable goals for wetland restoration. New wetlands should not be expected to perform the same way as established wetlands mainly because it can take anywhere from 30 to 100 years for the plant assemblages and structures of wetlands to resemble natural/established wetland conditions (Moreno-Mateos et al., 2012). Goals should be both short and long term with 
management plans tiered accordingly. The recommended short-term goal is to control the reed canary grass population while enhancing the resilience of this habitat through the assemblage of wetland plants in the area. The long-term goal should be to increase the wetland area.

Although there are only a few obligate wetland plants in the area, the seasonality of the wetland and the potential changes to our climate suggest that the best trait to focus on for this wetland community assemblage is the ability to persist in wetlands as well as in non-wetland conditions. Obligate species could still be beneficial, but most of the plants selected for enhancing current population or introducing with planting should be in the facultative spectrum (FACW, FAC, or FACU). With this approach, it is possible to create native plant diversity resilient to invasion while utilizing trait-based selections for resilience to climate change (Laughlin, 2017).

Reed canary grass is not a designated weed by the Oregon Department of Agriculture, but it is known to behave as an invasive species by dominating systems to the exclusion of native species (Kim et al., 2006). Live willow staking to produce shade in combination with herbicide application has been successfully used at other sites (Ewing, 2010; King et al., 2006). A native species of willow that is a hydrophyte should be select for this treatment (indicator codes OBL, FAC, OR FACW); this will meet both short-term goals by suppressing the reed canary grass and supporting the assembly of wetland species. Undergreen willow (Salix commutata Bebb) would be an excellent choice as it's an obligate hydrophyte (OBL) that grows in elevations from $0-2400 \mathrm{~m}$, can be propagated by cutting, has a maximum height of 20 feet (so it will not create much competition for the oaks), and is a palatable food source for browsing animals (USDA, NRCS, 2018; efloras.org, 2018). However, there are numerous willows that are classified as FACW and available nursery stock will greatly determine the species chosen here. Ideally, multiple willow species will be used to achieve the kind of biological and trait-based diversity previously discussed for a resilient ecosystem. Given the population of giant 
horsetail, a facultative wetland (FACW) hydrophyte, dominating the shaded area at the base of the slope, adjacent to the reed canary grass area, it is likely that this population will expand once the grass is suppressed. It will be important to reassess these conditions after the grass has been suppressed to determine if supplemental plantings are necessary to achieve the kind of native plant diversity that will be resilient to future invasion (Downing et al., 2012). Monitoring and managing invasive species in this area will require regular attention; bi-yearly inspections after the prescribed treatment would be ideal.

In the long-term, Metro should be prepared to acquire the immediately adjacent properties to the west, both above and below Dixon Mill Rd., and to the south in the path of the spring fed stream in an effort to create connectivity, enhance, and grow the wetland area in the future. Materials from nearby thinning operations could be used to create small dams along the southern park border, east of Poppy Dr., to establish another pool and extend the wetland habitat to the area south of the seasonal spring that is already providing surface water flow to the area (see Recommended Habitat Distribution map, Appendix B). Without any additional land acquisition, mimicking beaver activity with these small dams could increase the wetland habitat area to a total of 13.6 acres and provide additional pools to support waterfowl and amphibians in the park. Beavers are known to exist in CRNP; they may move into this area and naturally create (or maintain) the dams desired in this area as well.

There is a dense stand of young bigleaf maple ( $A$. macrophyllum) that could be thinned at the same time that oak treatments are done in the wetland area, preferably in late fall when conditions are dry and the soil is most stable to avoid compaction. This wood could be retained on site to enhance the wetland area as it is directly west of the proposed wetland habitat expansion. To minimize windthrow (Edmonds et al., 2011) as well as loss of canopy cover that may enhance invasive species, this section should be selectively thinned to remove the smallest trees and leave the largest trees to maximize 
canopy cover that will inhibit invasive species colonization. It may also be advisable to do a multi-year plan that leaves medium sized spacer trees between the largest trees to give them time to close the canopy before removing them 1-2 years later. This would also allow for adaptive management strategies to be applied to assess the results of each small damn installation using the wood from these periodic thinning operations.

Care should be taken to ensure the installations are stable and will not pose a threat to human life or property by collapsing or dislodging and creating a flash flood situation downstream. This may be accomplished in the design phase by setting a maximum structure height, using minimal materials to achieve it, incorporating spill paths into the structures, and planting fast growing woody species (like live willow staking) on both sides of the structures to provide extra support as well as help collect sediment moved by the water with shading to cool the water. However, an environmental engineer should be consulted for creating more detailed plans to ensure structural stability.

\section{Douglas-fir Forest}

By accelerating the development of old-growth forest structure, there is potential to enhance the overall quality and connectivity of habitat for the variety of animals found in CRNP that utilize the wetland, oak woodland, and middle to late seral stage Douglasfir forest including the Douglas squirrel, several amphibians, and numerous birds (Table 1). The selective logging prescriptions already being applied to the ridgetop portions should be extended along the Douglas-fir forest areas that book-end the east and west edges of the primary project area. Additionally, planting of shade tolerant understory species such as western hemlock (Tsuga heterophylla) and western red cedar (Thuja plicata) should be used to create a more natural, heterogeneous, mixed conifer forest and expedite the trajectory for old growth forest structure (Barnes et al, 1998; USDA Forest Service, 2016; Van Pelt, 2007). These two species are particularly good choices for the areas at the base of the slopes near the spring and wetland because they can also tolerate saturated conditions (T. hererophylla: FACW, T. plicata: FAC). 


\section{Invasive Species Management}

Oregon Metro has an integrated pest management plan (IPM) that is used for managing invasive species in the unit (Kate Holleran, personal communication). Therefore, this section will briefly touch on a few considerations that may support future planning activities. Most importantly, because invasive species management can drain almost any budget, it is important to make strategic decisions with realistic expectations. If decision analysis tools such as IPMDAT and WeedSearch are not already being utilized, employing such technology could help Metro devise strategic approaches for the management of invasive species in all of their natural areas (Corbin et al., 2017).

Invasive thistles have been found to be more sensitive to the insect predators of native species (Eckberg et al., 2017). Additionally, it has also been observed that native pollinators tend to favor native thistles over invasives when given a choice (Eckberg et al., 2017). The allelopathic qualities and vegetative reproductive capability of Canada thistle (Stachon \& Zimdahl, 1980; Wilson, 1981, Eckberg et al., 2017) should be a concern, especially in the wetland areas, and may warrant slightly more aggressive action to reduce/control population sizes. However, a more long-term management strategy may involve the strategic introduction of native thistles into the infested areas to attract more of the native predators and give the pollinators a more appealing food source, thereby reducing pollination rates while increasing predator and competition stress on the invasive populations. Eckberg et al (2017) provides excellent guidance for producing and planting native thistles.

Controlling the Himalayan blackberry in this unit will likely require a combination of herbicide application, hand-pulling, and shade creation. While yearly mowing of blackberry has been and effective control in places like the University of Washington's Union Bay Natural Area grasslands (Ewing, 2010), this technique would not be viable along the stream side (Figure 4), nor would it be appropriate to address the sporadic occurrences throughout the project area where many other plants would also be 
affected by the treatment. Increasing canopy cover in the area associated with the stream head at the Dixon Mill Rd. culvert may reduce its competitiveness (Ewing, 2010), but this is not currently an option for the patch along the western boundary fence as the area that would need trees planted is not part of the park property. The most effective way to remove this large clump would be to dig out its entire root system, though incomplete root removal will be insufficient (Ewing, 2010). Repeat treatments to find and remove the entire root system for this large clump should be planned. Alternatively, this species may be considered part of the novel community assemblage. Planting shade trees (e.g. live willow stakes (Ewing, 2010)) and salmon berry (Rubus spectabilis) in close proximity to large blackberry colonies could be used to increase the competition for this plant.

The shining geranium (Geranium lucidum) is so pervasive that eradication is unrealistic. The Washington State Noxious Weed Control Board recommends mulching to control it and herbicide application because hand pulling was found to be ineffective (WSNWCB, 2009). While herbicide application could be used in the area, great care should be taken to avoid unintended impacts to wetland habitat that is fed by the surface and groundwater of the adjacent slope. The amount of mulch required to treat all the affected area would be massive. However, selective mulch applications around the small snowberry and white oak seedlings that seem easily engulfed by this geranium may provide enough of a buffer to allow these plants to grow to a height that the geranium would not affect.

\section{Erosion Control}

\section{Fire Road}

The erosion and deepening of the drainage cuts that cross the fire road should be monitored closely. While the vegetation may help to slow soil erosion, large storm events could create enough water to destabilize a vegetation buffer. Additionally, roads and disturbed open areas like power line accesses and logging roads are well known to 
be highly susceptible to invasive species. These drainage routes may create both vectors for seeds moved by water along the drainage path, and ideal havens for colonizers as these cuts have water and higher light exposure, even in the areas where the conifers provide some shade to the road,

Because the fire road is being decommissioned, the natural erosion and revelation processes can be used to slowly return the graded road to a more natural topography. To minimize the potential need for heavy machinery projects, inspections should be scheduled near the end of every rainy season. Drainage cut dimensions should be tracked yearly with a width:depth threshold set that will trigger hand maintenance. I recommend maintaining a 2:1 ratio with a 1:1 ratio triggering maintenance planning for the following year and a 2:1 ratio triggering current year treatment. During maintenance, the drainage cuts should be widened, using material taken from the sides to fill in the bottom of the trench and remove any invasive species. When possible, this could also be timed to plant natives into the drainage cuts to create "priority effects" that may help establish desirable, but less competitive, species before problematic invasive species like ragweed move in. Care should be taken to create drainage pathways around new plants and ensure plants are planted as deeply as possible to give them the best chances at survival. Pickaxes and shovels should be adequate for this kind of regular maintenance.

\section{Culverts}

Both culverts seem to restrict the local hydrology with significant implications to erosion and habitat. The erosion underneath of the SW Dixon Mill Rd. culvert will eventually require attention as it reduces road stability. Replacing both these pipe culverts with open box style culverts would allow for more natural hydrologic flow as well as create habitat corridors for the chorus frogs to more easily traverse between the upper and lower wetland areas that straddle Dixon Mill Road (Jackson, 2003; Smith et al., 2018). However, because SW Poppy Rd. and its culvert are possible the cause of the developing 
seasonal wetland, putting in a box culvert here may be detrimental to maintaining the wetland habitat as it may reduce the amount pooling and duration of soil saturation in the immediate area. This road and culvert are essentially functioning similarly to a beaver dam, if removed the pooling and saturation resulting from the restricted hydrology will likely be reversed, converting this area to more oak woodland habitat. It is therefore advisable to install a box culvert specifically designed to reduce erosion and enhance amphibian crossing at the Dixon Mill Rd. culvert (Smith et al., 2018) and leave the SW Poppy Rd. culvert as it currently is.

\section{Accessibility}

This priority incorporates social/cultural and educational values into a single priority. Accessibility in this context can be achieved through a number of options including trails with interpretive signage, community outreach, and education. While the following recommendations are by no means an exhaustive list of options to accomplish this priority, they have been chosen to highlight for their practical and equitable features.

\section{Trails}

The cultural/social and educational value of this site would be greatly enhanced for the local community with the installation of trails and interpretive signage. Although the trails network for CRNP has already been planned without any trails in this unit (Kate Holleran, personal communication, 2018), the findings of this report may be useful for future revisions. Given the soil types and related erosion issues, especially during the

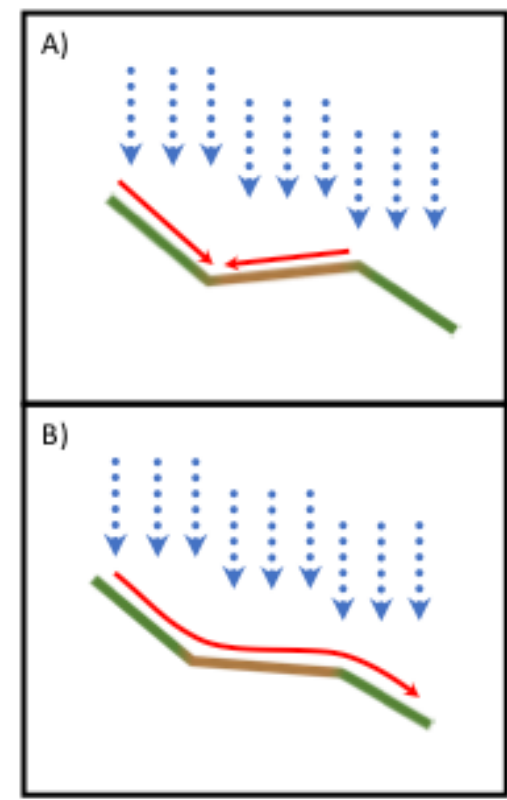

Figure 17: Example trail grading model to minimize erosion caused by surface runoff. The green lines represent the slope with the center brown portion being the trail, red arrows indicate the path of surface water from precipitation (blue arrows). A) The angle of the trail causes water to accumulate and cause erosion as it creates a channel along the inside edge of the trail. B) The path is flat enough to walk on, but the angle allows surface runoff to travel continuously down the slope, minimizing erosion caused by the channelization of water. 
wetter seasons, it is advisable to install some trail systems in this area to manage human activities and discourage widespread disturbance of the soil in this area. Because the soil type is so sensitive to erosion when exposed to channelized surface water runoff, it is important to consider how to reduce erosion when installing and maintaining trails in this area. Ensuring that trails are graded in ways to retain broad surface flow and prevent channelization can reduce the risk of erosion associated with maintained trails (Figure 19).

Because this area is so diverse in habitat with conifer forest, riparian wetlands, and oak habitat, it may be an ideal area to install an interpretive trail with educational signage about the various habitats. The wetland areas are quite inviting and a wonderful educational opportunity; installation of elevated trails through this section could be useful to protect the sensitive habitat as well as educate the public. Because so many of the invasive species areas of concern are in open areas closely related to the wetlands, trails could also be placed adjacent to these already invaded spaces to aid in monitoring and control. However, there is also increased potential for seeds to be spread by visitors. Installation of boot brushes and signage may help mitigate this issue. Additionally, these trails could be used to support the patchwork habitat structure by strategically placing them along the recommended habitat boundaries (see Recommended Habitat Distributions map, Appendix B). This would create an easily maintained distinction between the habitats that could aid in monitoring and management of the habitats. Establishing trails along habitat boundaries and through invasive species areas of concern would allow monitoring and treatment to be done with ease while also providing educational opportunities for the public.

Existing social trails come within close proximity to the adjacent residential properties, suggesting the local residents have enjoyed easy access to this natural area. This is something that should be carefully considered when trail installation is planned. Residents should be consulted regarding their desired degree of access as well as 
related privacy concerns. Privacy may be adequately addressed with proper trail signage designating small side access trails for residents only.

\section{Community Outreach}

Because the OWO habitat has significant Native American cultural value, accessibility to the oak habitat could be offered to The Confederation of Tribes of Grand Ronde as a cultural resource. Acorn gathering events could be organized that provide educational opportunities to the community about tribal culture and customs, provide a culturally important food source to the participating tribes (Anderson, 2007), and opportunities for Metro to enhance their tribal relations. Additionally, a portion of acorns from such events could be reserved for germination at Metro's Native Plant Nursery and used for the strategic oak plantings recommended above.

\section{Education}

Educational institutions can be wonderful partners for restoration projects. A common critique of restoration projects is a lack of monitoring and reporting post treatment (Bjorndal et al., 2011; Palmer et al., 2007; Zedler, 2000). Establishing a long-term monitoring project in partnership with a local school(s) would not only provide Metro with valuable data at little to no cost, it would also enhance the social and educational value of the site. Ideally, Metro would partner with a college or university where the project could be used to meet graduation requirements. However, with the installation of trails, less complex data collection for things like invasive species population size or conifer encroachment could easily be collected by students in grades $6-12$. Creating a comprehensive monitoring plan should be a priority for future partnerships between Metro and the Environmental Science and Management department at Portland State University. 


\section{Summary Statement}

The existing conditions found in the primary project area have promising implications for future ecological, cultural/social, and educational value. While conifer encroachment and invasive species warrant considerable attention, the existing patchwork habitat structure that includes a developing seasonal wetland and oak woodlands is a valuable opportunity to maintain two habitat types that have been greatly diminished over the last century. The relatively small size of the unit and ease of accessibility are promising features for management activities as well as opportunities for education and social enrichment. Unfortunately, finding the economic and human resources to implement the recommendations included this report may be prohibitive. Fortunately, there are currently no conditions that require intensive immediate action. Therefore, this report may also be useful for support and justification of future funding acquisition efforts as well as inspiration for a variety of potential research projects that could be used to implement and monitor various restoration activities. 


\section{$\underline{\text { References }}$}

Anderson, M. K. (2007). Indigenous uses, management, and restoration of oaks of the far western United States. Technical Note, United States Department of Agriculture Natural Resources Conservation Service, Washington DC, USA.

Barnes, B. V.; Zak, D. R8., Denton, S. R., Spurring, S. H. (1998). Forest ecology (4th ed.). New York: John Wiley \& Sons.

Bjorndal, K. A., Bowen, B. W., Chaloupka, M., Crowder, L. B., Heppell, S. S., Jones, C. M., Lutcavage, M. E., Policansky, D., Solow, A. R., \& Witherington, B. E. (2011). Better science needed for restoration in the Gulf of Mexico. Science, 331(6017), 537-538.

Bormann, B. T., Haynes, R. W., \& Martin, J. R. (2007). Adaptive management of forest ecosystems: did some rubber hit the road? AIBS Bulletin, 57(2), 186-191.

Burke Museum. (2018). Burke Herbarium Image Collection. Retrieved from: http://biology.burke.washington.edu/herbarium/imagecollection.php

Butterfield, B. J., Copeland, S. M., Munson, S. M., Roybal, C. M., \& Wood, T. E. (2017). Prestoration: using species in restoration that will persist now and into the future. Restoration Ecology, 25, S155-S163.

Chazdon, R. L., Blaise Bodin, M. G. U., David Lamb, B. W., \& Unna Chok-kalingam, K. S. (2017). Partnering with nature: The case for natural regeneration in forest and landscape restoration.

Corbin, J. D., Wolford, M., Zimmerman, C. L., \& Quirion, B. (2017). Assessing feasibility in invasive plant management: a retrospective analysis of garlic mustard (Alliaria petiolata) control. Restoration Ecology, 25, S170-S177.

Dalton, M. M., Dello, K. D., Hawkins, L., Mote, P. W., \& Rupp, D. E. (2017). The third Oregon climate assessment report. Oregon Climate Change Research Institute, College of Earth, Ocean, and Atmospheric Sciences, Oregon State University, Corvallis, Oregon.

Devine, W. D., \& Harrington, C. A. (2006). Changes in Oregon white oak (Quercus garryana Dougl. ex Hook.) following release from overtopping conifers. Trees, 20(6), 747-756.

Devine, W. D., \& Harrington, C. A. (2010). Planting native oak in the Pacific Northwest. Gen. Tech. Rep. PNW-GTR-804. Portland, OR: US Department of Agriculture, Forest Service, Pacific Northwest Research Station. 25 p., 804. 
Devine, W. D., \& Harrington, C. A. (2013). Restoration release of overtopped Oregon white oak increases 10 -year growth and acorn production. Forest ecology and management, 291, 87-95.

Devine, W. D., Harrington, C. A., \& Leonard, L. P. (2007). Post-planting treatments increase growth of Oregon white oak (Quercus garryana Dougl. ex Hook.) seedlings. Restoration Ecology, 15(2), 212-222.

Downing, A. S., van Nes, E. H., Mooij, W. M., \& Scheffer, M. (2012). The resilience and resistance of an ecosystem to a collapse of diversity. PloS one, 7(9), e46135.I

Dunwiddie, P. W., \& Bakker, J. D. (2011). The future of restoration and management of prairie-oak ecosystems in the Pacific Northwest. Northwest Science, 85(2), 83-92.

eFloras.org. (n.d.). Under-green willow. Retrieved 2018, from Flora of North America: http://www.efloras.org/florataxon.aspx?flora_id=1\&taxon_id=242445690

Eckberg, J., Lee-Mäder, E., Hopwood, J., Jordan, S. F., \& Borders, B. (2017). Native Thistles: A Conservation Practitioner's Guide. Plant Ecology, Seed Production Methods, and Habitat Restoration Opportunities.

Edmonds, R. L., Agee, J. K., \& Gara, R. I. (2011). Forest Health and Protection. Long Grove, IL: Waveland Press.

Environmental Laboratory. (1987). Corps of Engineers Wetlands Delineation Manual. Vicksburg, MS: U.S. Army Engineer Waterways Experiment Station.

Environmental Laboratory. (2010). Regional Supplement to the Corps of Engineers Wetland Delineation Manual: Western Mountains, Valleys, and Coast Region (Version 2.0). Vicksburg, MS: U.S. Army Engineer Waterways Experiment Station.

Ewing, K., Bakker, J., Fridley, J., Hoyt, F., Kim, S. H., Loudon, E., \& Reichard, S. (2010). Union Bay Natural Area and Shoreline Management Guidelines.

Fuchs, M. A., Krannitz, P. G., \& Harestad, A. S. (2000). Factors affecting emergence and first-year survival of seedlings of Garry oaks (Quercus garryana) in British Columbia, Canada. Forest Ecology and Management, 137(1-3), 209-219.

Garibaldi, A., \& Turner, N. (2004). Cultural keystone species: implications for ecological conservation and restoration. Ecology and society, 9(3). 
Gibson, D. J., Allstadt, A. J., Baer, S. G., \& Geisler, M. (2012). Effects of foundation species genotypic diversity on subordinate species richness in an assembling community. Oikos, 121(4), 496-507.

Gould, P. J., Harrington, C. A., \& Devine, W. D. (2011). Growth of Oregon white oak (Quercus garryana). Northwest Science, 85(2), 159-171.

Hanna, I., \& Dunn, P. (1996). Restoration goals for Oregon white oak habitats in the south Puget Sound region. Nature Conservancy of Washington.

Hobbs, R. J., Higgs, E., \& Harris, J. A. (2009). Novel ecosystems: implications for conservation and restoration. Trends in ecology \& evolution, 24(11), 599-605.

Hollingsworth, C. S. (2010). Pacific Northwest insect management handbook. Oregon State Extension Service. Retrieved from: https://pnwhandbooks.org/node/7233/print.

Huston, M. (1979). A general hypothesis of species diversity. The American Naturalist, 113(1), 81-101.

Jackson, S. D. (2003). Proposed design and considerations for use of amphibian and reptile tunnels in New England. University of Massachusetts Report.

Johnson, C. R., Chabot, R. H., Marzloff, M. P., \& Wotherspoon, S. (2017). Knowing when (not) to attempt ecological restoration. Restoration Ecology, 25(1), 140-147.

Kim, K. D., Ewing, K., \& Giblin, D. E. (2006). Controlling Phalaris arundinacea (reed canarygrass) with live willow stakes: a density-dependent response. Ecological Engineering, 27(3), 219-227.

Landres, P. B., Morgan, P., \& Swanson, F. J. (1999). Overview of the use of natural variability concepts in managing ecological systems. Ecological applications, 9(4), 11791188.

Laughlin, D. C., Strahan, R. T., Huffman, D. W., \& Sánchez Meador, A. J. (2017). Using trait-based ecology to restore resilient ecosystems: historical conditions and the future of montane forests in western North America. Restoration Ecology, 25, S135-S146.

Lautz, L. K., \& Fanelli, R. M. (2008). Seasonal biogeochemical hotspots in the streambed around restoration structures. Biogeochemistry, 91(1), 85-104.

LaRue, E. A., Chambers, S. M., \& Emery, N. C. (2017). Eco-evolutionary dynamics in restored communities and ecosystems. Restoration Ecology, 25(1), 19-26. 
Metro (2014), Site Conservation Plan, Chehalem Ridge Natural Area

Murcia, C., Aronson, J., Kattan, G. H., Moreno-Mateos, D., Dixon, K., \& Simberloff, D. (2014). A critique of the "novel ecosystem" concept. Trends in Ecology \& Evolution, 29(10), 548-553.

Mitsch, W. J., \& Gosselink, J. G. (2015). Wetlands (5th ed.). John Wiley \& Sons.

Mohr, C. H., Coppus, R., Iroumé, A., Huber, A., \& Bronstert, A. (2013). Runoff generation and soil erosion processes after clear cutting. Journal of Geophysical Research: Earth Surface, 118(2), 814-831.

Moreno-Mateos, D., Power, M. E., Comín, F. A., \& Yockteng, R. (2012). Structural and functional loss in restored wetland ecosystems. PloS biology, 10(1), e1001247.

National Cooperative Soil Survey. (2006a). Cove Series. Retrieved 2018, from OSD View by Name: https://soilseries.sc.egov.usda.gov/OSD_Docs/SAUM.html

National Cooperative Soil Survey. (2006b). Laurelwood Series. Retrieved 2018, from OSD View by Name: https://soilseries.sc.egov.usda.gov/OSD_Docs/LAURELWOOD.html

National Cooperative Soil Survey. (2006c). Saum Series. Retrieved 2018, from USDA Natural Resources Conservation Service:

https://soilseries.sc.egov.usda.gov/OSD_Docs/SAUM.htm

Niemiec, S. S., Ahrens, G. R., Willits, S., and Hibbs, D.E. (1995). Hardwoods of the Pacific Northwest.

NOAA, https://www.ncdc.noaa.gov/cdo-web/search

Oregon Department of Agriculture. (2018). Oregon Noxious Weed Profiles. Retrieved from Oregon Department of Agriculture:

https://www.oregon.gov/ODA/programs/Weeds/OregonNoxiousWeeds/Pages/AboutOr egonWeeds.aspx

Palmer, M. A., Bernhardt, E. S., Allan, J. D., Lake, P. S., Alexander, G., Brooks, S., Carr, J., Clayton, S., Dahm, C.N., Shah, J.F., \& Galat, D. L. (2005). Standards for ecologically successful river restoration. Journal of applied ecology, 42(2), 208-217.

Pellatt, M. G., \& Gedalof, Z. E. (2014). Environmental change in Garry oak (Quercus garryana) ecosystems: the evolution of an eco-cultural landscape. Biodiversity and conservation, 23(8), 2053-2067.

Pellatt, M. G., Goring, S. J., Bodtker, K. M., \& Cannon, A. J. (2012). Using a down-scaled 
bioclimate envelope model to determine long-term temporal connectivity of Garry oak (Quercus garryana) habitat in western North America: implications for protected area planning. Environmental Management, 49(4), 802-815.

Pellatt, M. G., McCoy, M. M., \& Mathewes, R. W. (2015). Paleoecology and fire history of Garry oak ecosystems in Canada: implications for conservation and environmental management. Biodiversity and Conservation, 24(7), 1621-1639.

Peter, D., \& Harrington, C. (2002). Site and Tree Factors in Oregon region White Oak Acorn Production in Western Washington. Northwest Science, 76(3), 189.

Peterson, D. L. (2018, April 10). Buying Time in a Warmer Climate: From Restoration to Resilience. Speech presented at 2018 Symposium Restoration in a Changing Climate: Adapting Practices to Meet Long-term Goals in University of Washington Botanic Gardens Center for Urban Horticulture, Seattle, WA.

Pojar, J., \& MacKinnon, A. (1994). Plants of the Pacific Northwest Coast: Washington, Oregon, British Columbia \& Alaska. BC Ministry of Forests and Lone Pine Publishing. Vancouver. British Columbia.

Rieger, J. P., Stanley, J., \& Traynor, R. (2014). Project Planning and Management for Ecological Restoration. Washington, DC: Island Press.

SER (Society for Ecological Restoration International Science \& Policy Working Group). (2004). The SER International Primer on Ecological Restoration. SER, Tucson, AZ. Society for Ecological Restoration International. Available from: www.ser.or

Smith, R.K., Meredith, H. \& Sutherland, W.J. (2018) Amphibian Conservation. Pages 9-65 in: W.J. Sutherland, L.V. Dicks, N. Ockendon, S.O. Petrovan \& R.K. Smith (eds) What Works in Conservation 2018. Open Book Publishers, Cambridge, UK.

Spasojevic, M. J., Bahlai, C. A., Bradley, B. A., Butterfield, B. J., Tuanmu, M. N., Sistla, S., R. Wiederholt \& Suding, K. N. (2016). Scaling up the diversity-resilience relationship with trait databases and remote sensing data: the recovery of productivity after wildfire. Global Change Biology, 22(4), 1421-1432.

Stachon, W. J., \& Zimdahl, R. L. (1980). Allelopathic activity of Canada thistle (Cirsium arvense) in Colorado. Weed Science, 28(1), 83-86.

Suding, K. N., Gross, K. L., \& Houseman, G. R. (2004). Alternative states and positive feedbacks in restoration ecology. Trends in Ecology \& Evolution, 19(1), 46-53.

The Intertwine Alliance. 2012. Biodiversity Guide for the Greater Portland-Vancouver Region. A. Sihler, editor. The Intertwine Alliance, Portland, OR. www.theintertwine.org 
Thilenius, J. F. (1968). The Quercus garryana forests of the Willamette valley, Oregon. Ecology, 49(6), 1124-1133.

Thompson, J. (2007). Move over, Douglas-fir: Oregon white oaks need room to grow. Science Findings 98. Portland, OR: US Department of Agriculture, Forest Service, Pacific Northwest Research Station. 6 p., 98.

Tonina, D., \& Buffington, J. M. (2007). Hyporheic exchange in gravel bed rivers with pool-riffle morphology: Laboratory experiments and three-dimensional modeling. Water Resources Research, 43(1).

USDA, Forest Service. (2016). Green Mountain Project Draft Environmental Impact Statement. Willamette National Forest, McKenzie River Ranger District. Lane County, OR: USDA.

USDA, NRCS. (2018). The PLANTS Database (http://plants.usda.gov, 28 October 2018). National Plant Data Team, Greensboro, NC 27401-4901 USA.

Van Pelt, R. (2007). Identifying mature and old forests in western Washington. Washington State Department of Natural Resources.

Verhoeven, J. T., Arheimer, B., Yin, C., \& Hefting, M. M. (2006). Regional and global concerns over wetlands and water quality. Trends in Ecology \& Evolution, 21(2), 96-103.

Vesely, D., \& Tucker, G. (2004). A landowner's guide for restoring and managing Oregon white oak habitats.

White, P. S., \& Walker, J. L. (1997). Approximating nature's variation: selecting and using reference information in restoration ecology. Restoration Ecology, 5(4), 338-349.

Wilken, D., \& Burgher, J. (2000). Plant Guide, OREGON OAK Quercus garryana Dougl. ex Hook. [PDF]. USDA, NRCS, The PLANTS database. From: https://plants.sc.egov.usda.gov/java/factSheet?sort=symbol

Wilson Jr, R. G. (1981). Effect of Canada thistle (Cirsium arvense) residue on growth of some crops. Weed Science, 159-164.

WSNWCB (Washington State Noxious Weed Control Board). (2009). Shiny Geranium, Geranium lucidum. Retrieved August 13, 2018, from https://www.nwcb.wa.gov/weeds/shiny-geranium

Zedler, J.B, (200). Progress in wetland restoration ecology. Trends in Ecology and Evolution, 15, $402-407$. 
Appendix A - Botanical Species Information

\begin{tabular}{|c|c|c|c|c|c|c|c|c|c|c|}
\hline & \multicolumn{10}{|c|}{ BOTANICAL SUMMARY TABLE } \\
\hline & \multicolumn{5}{|c|}{ Habitat Type } & \multicolumn{5}{|c|}{ Wetland Status } \\
\hline & $\begin{array}{c}\text { Open } \\
\text { Canopy }\end{array}$ & $\begin{array}{c}\text { Wetland } \\
\text { \& Riparian }\end{array}$ & $\begin{array}{c}\text { Douglas-fir } \\
\text { Forest }\end{array}$ & $\begin{array}{c}\text { Oak } \\
\text { Woodland }\end{array}$ & $\begin{array}{c}\text { Fire } \\
\text { Road }\end{array}$ & FAC & FACU & FACW & OBL & UK \\
\hline Species Counts: & 18 & 33 & 29 & 31 & 18 & 10 & 23 & 4 & 2 & 20 \\
\hline Unique to Each Habitat: & 0 & 10 & 9 & 9 & 2 & N/A & N/A & N/A & N/A & $\mathrm{N} / \mathrm{A}$ \\
\hline \multicolumn{2}{|c|}{ Species in ALL Project Area Habitats: } & \multicolumn{3}{|c|}{15} & $\mathrm{~N} / \mathrm{A}$ & N/A & N/A & N/A & N/A & $\mathrm{N} / \mathrm{A}$ \\
\hline Species in Open Can & opy and: & 6 & 5 & 12 & 9 & 2 & 7 & 0 & 0 & 8 \\
\hline \multicolumn{3}{|c|}{ Species in Wetland/Riparian and: } & 18 & 20 & 6 & 8 & 13 & 4 & 2 & 6 \\
\hline \multicolumn{4}{|c|}{ Species in Douglas-fir and: } & 17 & 7 & 6 & 13 & 1 & 0 & 9 \\
\hline \multicolumn{5}{|c|}{ Species in Oak Woodland and: } & 10 & 6 & 15 & 0 & 1 & \\
\hline
\end{tabular}

\begin{tabular}{|c|c|c|c|c|c|c|c|}
\hline \multicolumn{9}{|c|}{ BOTANICAL SPECIES LIST } \\
\hline FAMILY & GENUS (USDA) & SPECIES & AUTHORITY & NATIVE STATUS & COMMON NAME & $\begin{array}{c}\text { HABITAT } \\
\text { TYPE }\end{array}$ & $\begin{array}{c}\text { WETLAND } \\
\text { STATUS }\end{array}$ \\
\hline Aceraceae & Acer & macrophyllum & (L.) Scop. & native & big leaf maple & All & FACU \\
\hline Asteraceae & Achillea & millefolium & Focke & native & common yarrow & $\begin{array}{c}\text { Open areas, } \\
\text { all habitat types }\end{array}$ & \begin{tabular}{c} 
FACU \\
\hline
\end{tabular}
\end{tabular}




\begin{tabular}{|c|c|c|c|c|c|c|c|}
\hline \multicolumn{8}{|c|}{ BOTANICAL SPECIES LIST } \\
\hline FAMILY & GENUS (USDA) & SPECIES & AUTHORITY & NATIVE STATUS & COMMON NAME & $\begin{array}{l}\text { HABITAT } \\
\text { TYPE }\end{array}$ & $\begin{array}{l}\text { WETLAND } \\
\text { STATUS }\end{array}$ \\
\hline Ericaceae & Arbutus & menziesii & Lindl. & native & Pacific madrone & $\begin{array}{c}\text { Douglas-fir Forest, } \\
\text { Oak Woodlands, } \\
\text { Fire Road (not } \\
\text { found in primary } \\
\text { project area) }\end{array}$ & UK \\
\hline Convolvulaceae & Calystegia & $s p$ & (L.) Link & UK & false bindweed & $\begin{array}{l}\text { Open areas, } \\
\text { fire road }\end{array}$ & UK \\
\hline Asparagaceae & Camassia & leichtlinii & Pursh & native & $\begin{array}{c}\text { large camas, purple } \\
\text { camas }\end{array}$ & Wetland, Riparian & FACW \\
\hline Rhamnaceae & Ceanothus & sanguineus & A.Heller & native & red stem ceanothus & $\begin{array}{l}\text { Open areas, } \\
\text { fire road }\end{array}$ & UK \\
\hline Gentianaceae & Centaurium & $s p$ & R. Bolli & UK & centaury & $\begin{array}{l}\text { Open areas, } \\
\text { fire road }\end{array}$ & UK \\
\hline $\begin{array}{l}\text { Asteraceae / } \\
\text { Compositae }\end{array}$ & Cichorium & intybus & $\begin{array}{c}\text { (Torr. \& A. Gray) } \\
\text { Greene }\end{array}$ & non native & chicory & $\begin{array}{c}\text { Open areas, } \\
\text { near road }\end{array}$ & FACU \\
\hline Asteraceae & Cirsium & vulgare & L. & $\begin{array}{l}\text { "B" designated } \\
\text { weed }\end{array}$ & $\begin{array}{l}\text { bull thistle, } \\
\text { common thistle }\end{array}$ & $\begin{array}{c}\text { Open areas, } \\
\text { Riparian, } \\
\text { Oak Woodland }\end{array}$ & FACU \\
\hline Asteraceae & Cirsium & arvense & L. & $\begin{array}{l}\text { "B" designated } \\
\text { weed }\end{array}$ & Canada thistle & $\begin{array}{c}\text { Open areas, } \\
\text { all habitat types }\end{array}$ & FAC \\
\hline Betulaceae & Corylus & cornuta & L. & native & $\begin{array}{l}\text { beaked hazelnut, } \\
\text { California hazelnut }\end{array}$ & All, widespread & FACU \\
\hline Rosaceae & Crataegus & $s p$ & (Savi) Ten. & UK & hawthorn & Douglas-fir Forest & UK \\
\hline $\begin{array}{l}\text { Fabaceae / } \\
\text { Leguminosae }\end{array}$ & Cytisus & scoparius & L. & $\begin{array}{c}\text { "B" designated } \\
\text { weed }\end{array}$ & scot's broom & All, but scarce & UK \\
\hline $\begin{array}{c}\text { Apiaceae / } \\
\text { Umbelliferae }\end{array}$ & Daucus & carota & Pursh & non native & Queen Anne's lace & $\begin{array}{c}\text { Open areas, } \\
\text { all habitat types }\end{array}$ & FACU \\
\hline Equisetaceae & Equisetum & telmateia & L. & Native & giant horsetail & Riparian, Wetland & FACW \\
\hline
\end{tabular}




\begin{tabular}{|c|c|c|c|c|c|c|c|}
\hline \multicolumn{8}{|c|}{ BOTANICAL SPECIES LIST } \\
\hline FAMILY & GENUS (USDA) & SPECIES & AUTHORITY & NATIVE STATUS & COMMON NAME & $\begin{array}{l}\text { HABITAT } \\
\text { TYPE }\end{array}$ & $\begin{array}{l}\text { WETLAND } \\
\text { STATUS }\end{array}$ \\
\hline Oleaceae & Fraxinus & latifolia & (Pursh.) Maxim & native & Oregon ash & $\begin{array}{l}\text { Douglas-fir Forest, } \\
\text { Riparian, Wetland, }\end{array}$ & FACW \\
\hline Rubiaceae & Galium & $s p$ & (Pursh.) Nutt. & UK & bedstraw & Douglas-fir Forest & UK \\
\hline Geraniaceae & Geranium & lucidum & (Pursh.) Kuntze & $\begin{array}{l}\text { "B" designated } \\
\text { weed }\end{array}$ & $\begin{array}{l}\text { shining crane's bill, } \\
\text { shining geranium }\end{array}$ & All, widespread & UK \\
\hline Araliaceae & Hedera & $s p$. & (Kaulf.) C. Presl & $\begin{array}{l}\text { "B" designated } \\
\text { weed }\end{array}$ & ivy & $\begin{array}{l}\text { Wetland, Riparian, } \\
\text { Douglas-fir Forest, } \\
\text { fire road }\end{array}$ & UK \\
\hline Rosaceae & Holodiscus & discolor & L. & native & oceanspray & Wetland, Riparian & FACU \\
\hline Boraginaceae & Hydrophyllum & tenuipes & (Mirb.) Franco & native & Pacific waterleaf & Wetland, Riparian & FAC \\
\hline $\begin{array}{l}\text { Clusiaceae / } \\
\text { Guttiferae }\end{array}$ & Hypericum & perforatum & (L.) Kuhn & $\begin{array}{l}\text { "B" designated } \\
\text { weed }\end{array}$ & St. John's wort & $\begin{array}{l}\text { Open areas, } \\
\text { Oak Woodland } \\
\text { (near road) }\end{array}$ & FACU \\
\hline $\begin{array}{c}\text { Asteraceae / } \\
\text { Compositae }\end{array}$ & Hypochaeris & radicata & Douglas ex Hook. & non native & common catsear & $\begin{array}{l}\text { Open areas, } \\
\text { roadside }\end{array}$ & FACU \\
\hline Aquifoliaceae & Ilex & aquifolium & Cham. \& Schltdl. & non native & English holly & Douglas-fir Forest & FACU \\
\hline Iridaceae & Iris & tenax & L. & native & $\begin{array}{l}\text { toughleaf iris, Oregon } \\
\text { iris }\end{array}$ & $\begin{array}{c}\text { Open areas, } \\
\text { Douglas-fir Forest, }\end{array}$ & UK \\
\hline $\begin{array}{l}\text { Asteraceae / } \\
\text { Compositae }\end{array}$ & Lapsana & communis & Marshall & non native & common nipplewort & Douglas-fir Forest & FACU \\
\hline $\begin{array}{l}\text { Fabaceae / } \\
\text { Leguminosae }\end{array}$ & Lathyrus & latifolius & DC. & $\begin{array}{l}\text { "B" designated } \\
\text { weed }\end{array}$ & $\begin{array}{c}\text { perennial pea, } \\
\text { everlasting peavine, } \\
\text { perennial sweatpea }\end{array}$ & $\begin{array}{c}\text { Open areas, fire } \\
\text { road }\end{array}$ & UK \\
\hline $\begin{array}{l}\text { Asteraceae / } \\
\text { Compositae }\end{array}$ & Leucanthemum & $s p$ & (L.) S.F.Blake & non native & daisy & $\begin{array}{l}\text { Open areas, } \\
\text { roadside, Oak } \\
\text { Woodland }\end{array}$ & UK \\
\hline $\begin{array}{c}\text { Fabaceae / } \\
\text { Leguminosae }\end{array}$ & Lupinus & polyphyllus & L. & native & bigleaf lupine & $\begin{array}{l}\text { Open areas, all } \\
\text { habitat types }\end{array}$ & FAC \\
\hline
\end{tabular}




\begin{tabular}{|c|c|c|c|c|c|c|c|}
\hline \multicolumn{8}{|c|}{ BOTANICAL SPECIES LIST } \\
\hline FAMILY & GENUS (USDA) & SPECIES & AUTHORITY & NATIVE STATUS & COMMON NAME & $\begin{array}{l}\text { HABITAT } \\
\text { TYPE }\end{array}$ & $\begin{array}{l}\text { WETLAND } \\
\text { STATUS }\end{array}$ \\
\hline Berberidaceae & Mahonia & aquifolium & L. & native & tall Oregon grape & Douglas-fir Forest & FACU \\
\hline Asparagaceae & Maianthemum & stellatum & L. & native & $\begin{array}{c}\text { starry false lily of the } \\
\text { valley }\end{array}$ & Wetland, Riparian & FAC \\
\hline Cucurbitaceae & Marah & oreganus & $\mathrm{L}$. & native & coastal man root & Wetland, Riparian & UK \\
\hline Scrophulariaceae & Mimuluis & $s p$ & $\mathrm{~L}$. & native & monkey flower & Wetland, Riparian & $\mathrm{OBL}$ \\
\hline $\begin{array}{l}\text { Asteraceae / } \\
\text { Compositae }\end{array}$ & Mycelis & muralis & L. & non native & wall-lettuce & Douglas-fir Forest & UK \\
\hline Apiaceae & Oenanthe & sarmentosa & $\begin{array}{l}\text { (Baker) S. } \\
\text { Watson }\end{array}$ & native & $\begin{array}{c}\text { Pacific water- } \\
\text { dropwort } \\
\text { American water- } \\
\text { parsley } \\
\end{array}$ & $\begin{array}{c}\text { Wetland, } \\
\text { Oak Woodland }\end{array}$ & OBL \\
\hline Apiaceae & Osmorhiza & berteroi & Ehrh. & native & sweet cicely & Wetland, Riparian & FACU \\
\hline Scrophulariaceae & Penstemon & $s p$ & Benth. & UK & beardtongue & $\begin{array}{c}\text { Open areas, fire } \\
\text { road }\end{array}$ & UK \\
\hline $\begin{array}{l}\text { Poaceae / } \\
\text { Gramineae }\end{array}$ & Phalaris & arundinacea & L. & non native & reed canary grass & Wetland, Riparian & FACW \\
\hline Rosaceae & Physocarpus & capitatus & L. & native & Pacific ninebark & $\begin{array}{l}\text { Oak Woodland, } \\
\text { Riparian, Wetland }\end{array}$ & FACU \\
\hline Dryopteridaceae & Polystichum & munitum & C. Presl ex DC. & native & sword fern & $\begin{array}{l}\text { Riparian, Wetland, } \\
\text { Douglas-fir Forest }\end{array}$ & FACU \\
\hline $\begin{array}{l}\text { Lamiaceae / } \\
\text { Labiatae }\end{array}$ & Prunella & vulgaris & (L.) Link & native & common selfheal & $\begin{array}{l}\text { Open areas, } \\
\text { Oak Woodland } \\
\text { (near road) }\end{array}$ & FACU \\
\hline Rosaceae & Prunus & $s p$ & L. & UK & plum or cherry & Oak Woodland & UK \\
\hline Pinaceae & Pseudotsuga & menziesii & L. & native & Douglas-fir & $\begin{array}{l}\text { Douglas-fir Forest, } \\
\text { Oak Woodlands }\end{array}$ & FACU \\
\hline Dennstaedtiaceae & Pteridium & aquilinum & L. & native & bracken fern & $\begin{array}{l}\text { Riparian, Wetland, } \\
\text { Oak Woodland }\end{array}$ & FACU \\
\hline
\end{tabular}




\begin{tabular}{|c|c|c|c|c|c|c|c|}
\hline \multicolumn{8}{|c|}{ BOTANICAL SPECIES LIST } \\
\hline FAMILY & GENUS (USDA) & SPECIES & AUTHORITY & NATIVE STATUS & COMMON NAME & $\begin{array}{l}\text { HABITAT } \\
\text { TYPE }\end{array}$ & $\begin{array}{l}\text { WETLAND } \\
\text { STATUS }\end{array}$ \\
\hline Fagaceae & Quercus & garryana & Pursh & native & $\begin{array}{c}\text { Oregon white oak, } \\
\text { Garry oak }\end{array}$ & All & FACU \\
\hline Rosaceae & Rosa & $s p$ & Douglas ex Lindl. & UK & rose & All & UK \\
\hline Rosaceae & Rubus & armeniacus & $\begin{array}{c}\text { (Torr. Ex S. } \\
\text { Watson) Howell }\end{array}$ & $\begin{array}{c}\text { "B" designated } \\
\text { weed }\end{array}$ & Himalayan blackberry & All & FAC \\
\hline Rosaceae & Rubus & ursinus & Pursh & native & $\begin{array}{c}\text { California blackberry, } \\
\text { trailing blackberry }\end{array}$ & All, but scarce & FACU \\
\hline Rosaceae & Rubus & spectabilis & Mill. & native & salmonberry & All, & FAC \\
\hline Polygonaceae & Rumex & obtusifolius & L. & non native & bitter dock & Oak Woodland & FAC \\
\hline Salicaceae & Salix & $s p$. & R. Br. & UK & willow & $\begin{array}{l}\text { Open areas, Oak } \\
\text { Woodland, } \\
\text { Wetland }\end{array}$ & UK \\
\hline Caprifoliaceae & Sambucus & $\begin{array}{c}\text { nigra } \\
\text { ssp. cerulea }\end{array}$ & Hill & native & blue elderberry & All & FAC \\
\hline $\begin{array}{l}\text { Asteraceae / } \\
\text { Compositae }\end{array}$ & Senecio & jacobaea & L. & $\begin{array}{c}\text { "B" and "T" } \\
\text { designated weed }\end{array}$ & $\begin{array}{l}\text { tansy ragwort, } \\
\text { stinking willie }\end{array}$ & $\begin{array}{c}\text { Oak Woodland, fire } \\
\text { road }\end{array}$ & FACU \\
\hline Solanaceae & Solanum & dulcamara & $\mathrm{L}$. & non native & climbing nightshade & Riparian & FAC \\
\hline Solanaceae & Solanum & $s p$ & Schmidel & UK & nightshade & $\begin{array}{c}\text { Open areas, Oak } \\
\text { Woodland } \\
\text { (roadside) }\end{array}$ & UK \\
\hline Caprifoliaceae & Symphoricarpos & albus & L. & native & snowberry & $\begin{array}{c}\text { Riparian, Doug-fir } \\
\text { forest, } \\
\text { Oak Woodland }\end{array}$ & FACU \\
\hline Anacardiaceae & Toxicodendron & diversilobum & L. & native & $\begin{array}{c}\text { green Pacific poison } \\
\text { oak } \\
\end{array}$ & Douglas-fir Forest & FAC \\
\hline $\begin{array}{l}\text { Fabaceae/ } \\
\text { Leguminosae }\end{array}$ & Trifolium & $s p$ & L. & UK & clover & $\begin{array}{l}\text { Open areas, fire } \\
\text { road }\end{array}$ & UK \\
\hline
\end{tabular}




\begin{tabular}{|c|c|c|c|c|c|c|c|}
\hline \multicolumn{7}{|c|}{ BOTANICAL SPECIES LIST } \\
\hline FAMILY & GENUS (USDA) & SPECIES & AUTHORITY & NATIVE STATUS & COMMON NAME & $\begin{array}{c}\text { HABITAT } \\
\text { TYPE }\end{array}$ & $\begin{array}{c}\text { WETLAND } \\
\text { STATUS }\end{array}$ \\
\hline Scrophulariaceae & Verbascum & thapsus & L. & non native & common mullein & $\begin{array}{c}\text { Open areas, Oak } \\
\text { Woodland }\end{array}$ & \begin{tabular}{c} 
FACU \\
\hline Violaceae
\end{tabular} \\
Viola & canadensis & L. & native & Canadian white violet & Douglas-fir Forest & FACU \\
\hline
\end{tabular}

Wetland Status Abbreviations Key

(Definitions from USDA Plants Database: www.plants.usda.gov)

\begin{tabular}{|c|l|}
\hline FAC & Facultative - Hydrophyte species that "occurs in wetlands and non-wetlands". \\
\hline FACU & Facultative Upland - Hydrophyte species that "usually occur in non-wetlands but may occur in wetlands". \\
\hline FACW & Facultative Wetland - Hydrophyte species that "usually occur in wetlands but may occur in non-wetlands". \\
\hline OBL & Obligate Wetland - Hydrophyte species that "almost always occur in wetlands". \\
\hline UK & Unknown - not wetland status listed in database. \\
\hline
\end{tabular}


Authority Abbreviations Key

\begin{tabular}{|c|l|}
\hline Abbreviation & \multicolumn{1}{|c|}{ Botanist } \\
\hline A. Gray & Asa Gray \\
\hline A. Heller & Amos Arthur Heller \\
\hline Baker & John Gilbert Baker \\
\hline Benth. & George Bentham \\
\hline Cham. & Adelbert von Chamisso \\
\hline C. Presl & Carl Borivoj Presl \\
\hline DC. & Augustin Pyramus de Candolle \\
\hline Douglas & David Douglas \\
\hline Ehrh. & Jakob Friedrich Ehrhart \\
\hline Focke & Wilhelm Olbers Focke \\
\hline Franco & João Manuel Antonio do Amaral Franco \\
\hline Greene & Edward Lee Greene \\
\hline Hill & John Hill \\
\hline Hook. & William Jackson Hooker \\
\hline Howell & Thomas Jefferson Howell \\
\hline Kaulf. & Georg Friedrich Kaulfuss \\
\hline Kuhn & Friedrich Adalbert Maximilian Kuhn \\
\hline Kuntze & Carl Ernst Otto Kuntze \\
\hline L. & Carl Linnaeus \\
\hline
\end{tabular}

\begin{tabular}{|c|l|}
\hline Abbreviation & \multicolumn{1}{|c|}{ Botanist } \\
\hline Lindl. & John Lindley \\
\hline Link & Johann Heinrich Friedrich Link \\
\hline Marshall & Humphry Marshall \\
\hline Maxim & Carl Maximowicz \\
\hline Mill. & Philip Miller \\
\hline Mirb. & Charles-François Brisseau de Mirbel \\
\hline Nutt. & Thomas Nuttall \\
\hline Pursh & Frederick Traugott Pursh \\
\hline R. Bolli & Richard Bolli \\
\hline R. Br. & Robert Brown \\
\hline Savi & Gaetano Savi \\
\hline Schltdl. & $\begin{array}{l}\text { Diederich Franz Leonhard von } \\
\text { Schlechtendal }\end{array}$ \\
\hline Schmidel & Casimir Christoph Schmidel \\
\hline Scop. & Giovanni Antonio Scopoli \\
\hline S.F.Blake & Sidney Fay Blake \\
\hline S. Watson & Sereno Watson \\
\hline Ten. & Michele Tenore \\
\hline Torr. & John Torrey \\
\hline & \\
\hline
\end{tabular}




\section{$\underline{\text { Appendix B - Maps }}$}

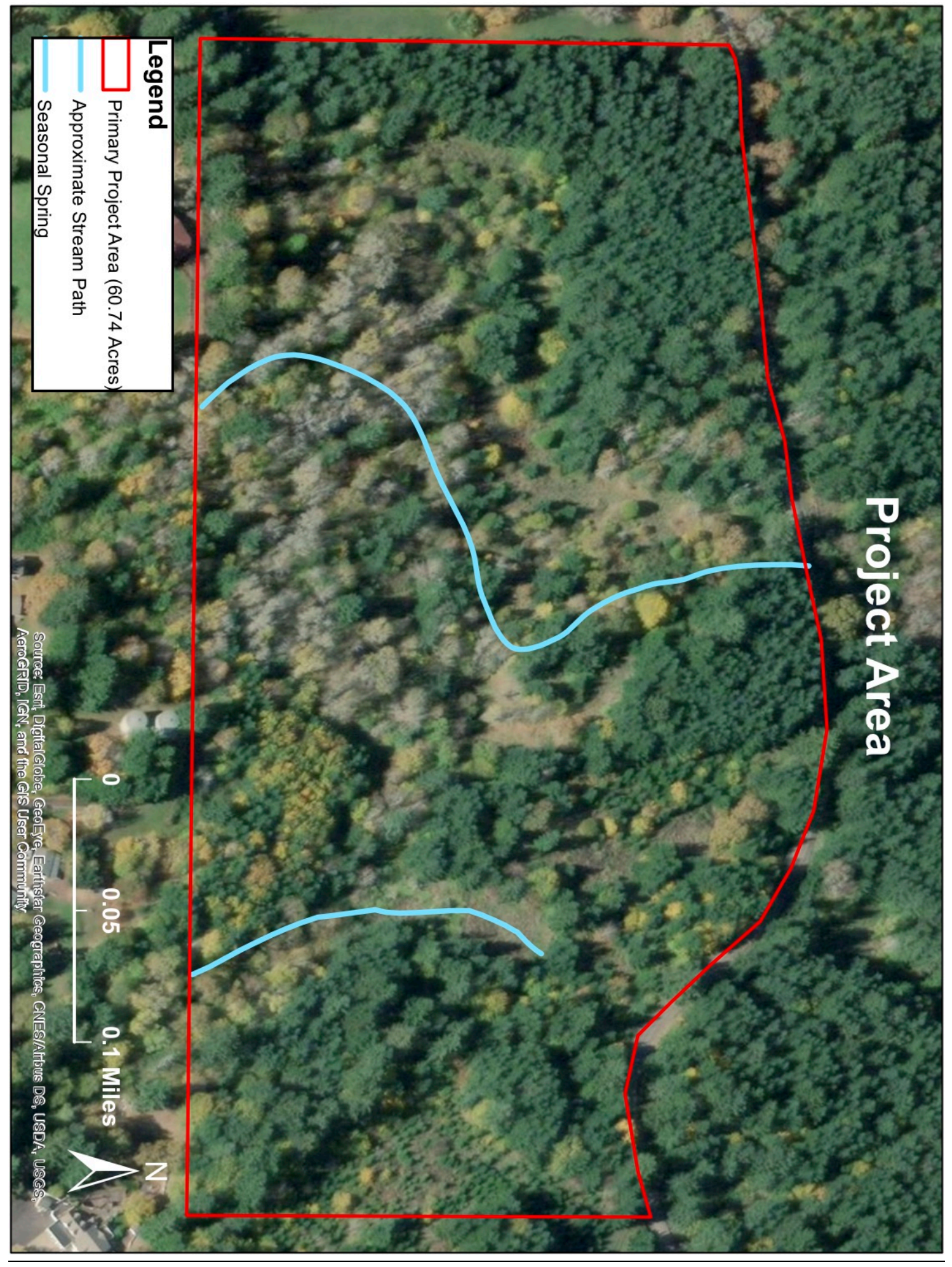




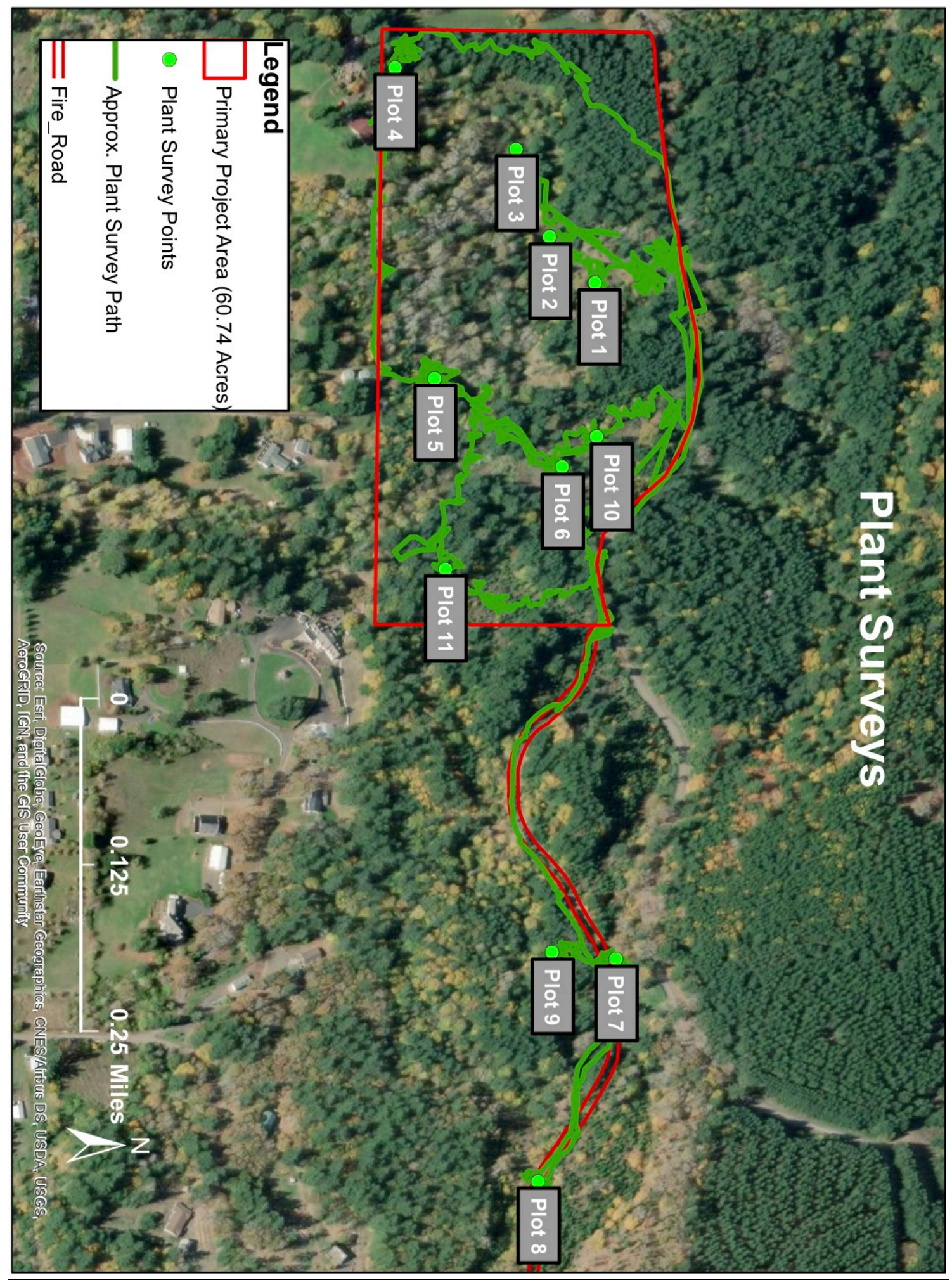




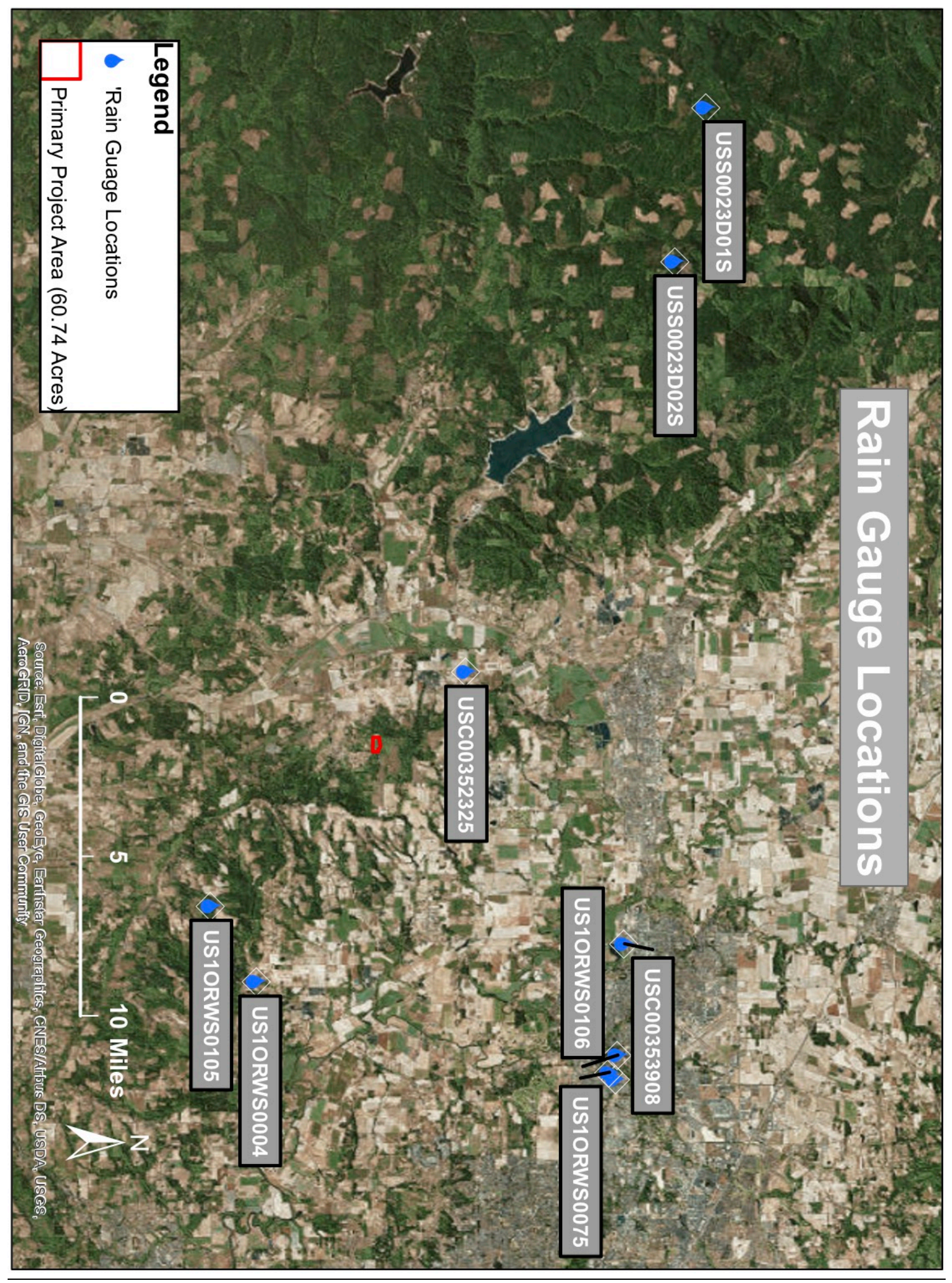




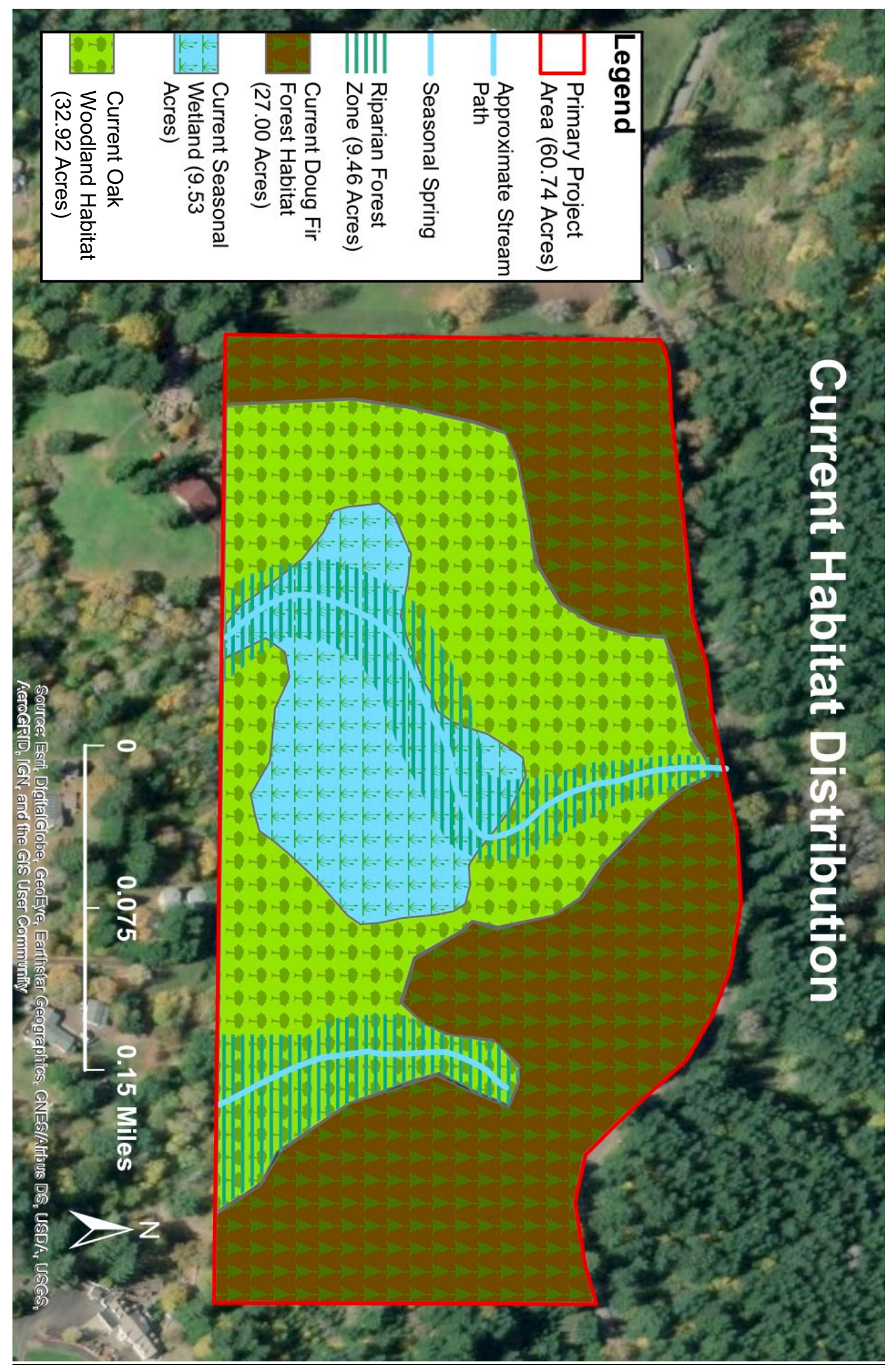




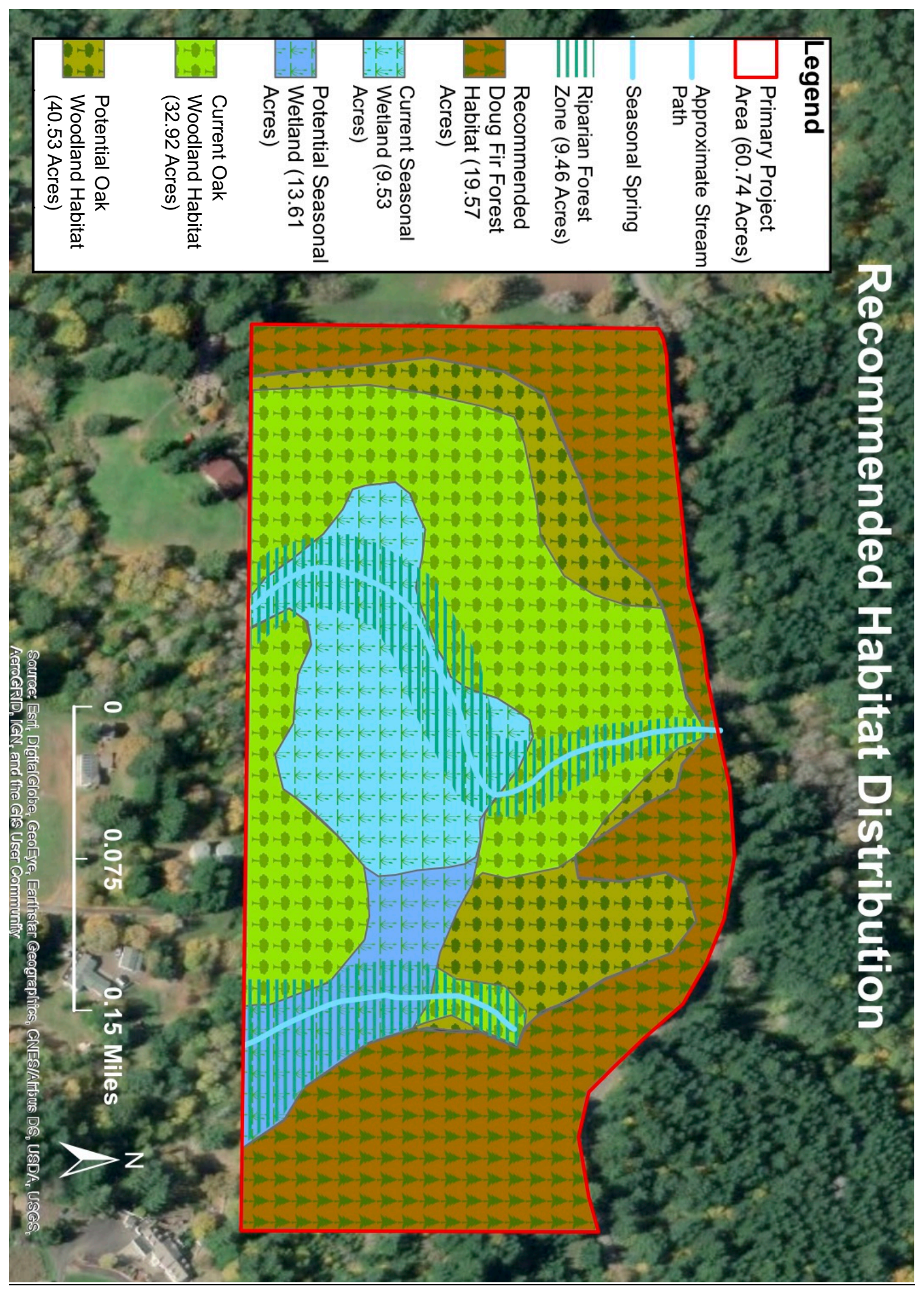




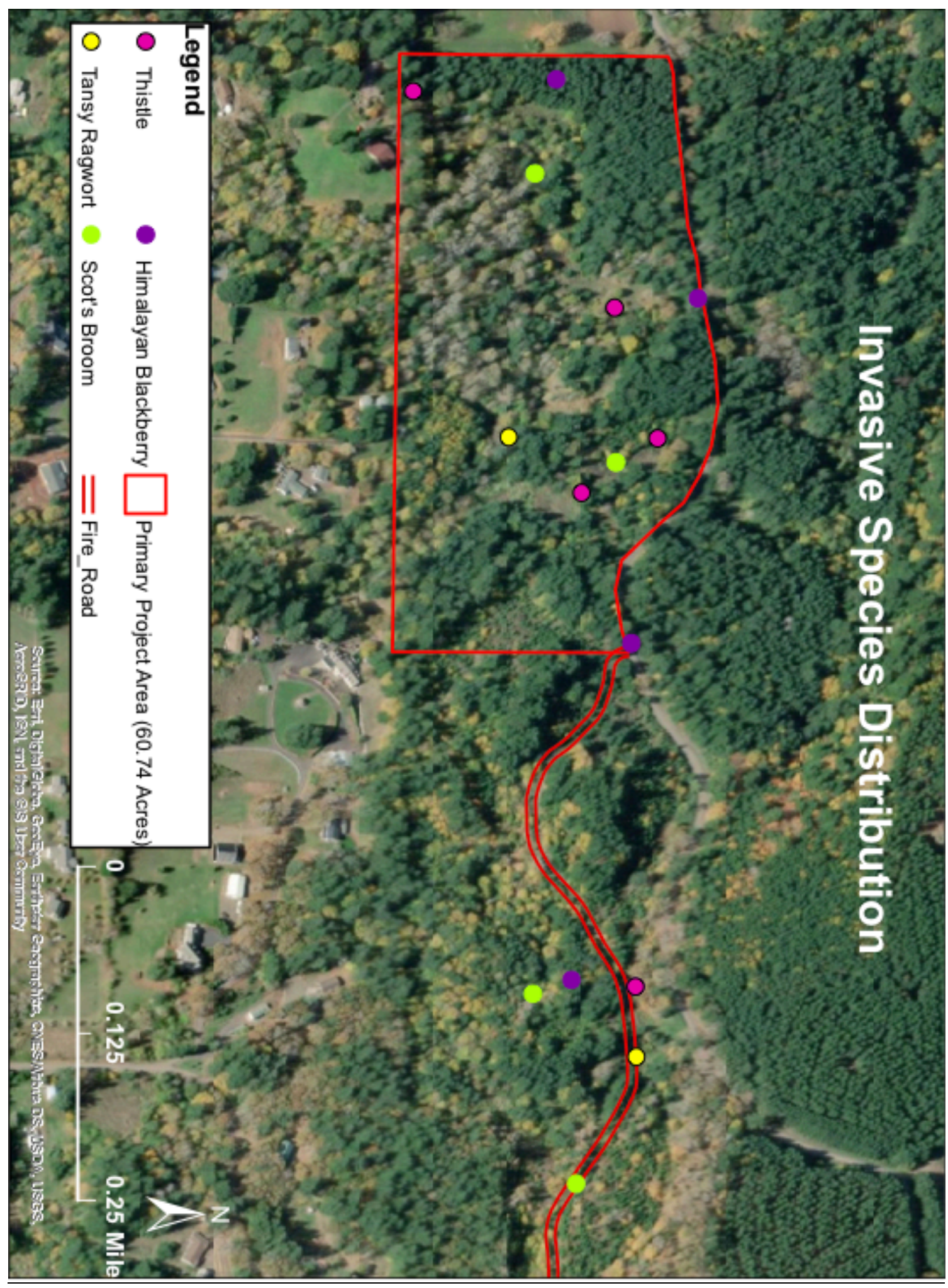

